\title{
$1 \quad$ Ionizing radiation improves RIG-I mediated immunotherapy 2 through enhanced p53 activation in malignant melanoma
}

$\underline{\text { Silke Lambing }}{ }^{\mathrm{a}}$, Stefan Holdenrieder ${ }^{\mathrm{a}, \mathrm{c}}$, Patrick Müller ${ }^{\mathrm{a}}$, Christian Hagen ${ }^{\mathrm{a}}$, Stephan Garbe ${ }^{\mathrm{b}}$, Martin Schlee $^{\mathrm{a}}$, Jasper G. van den Boorn ${ }^{\mathrm{a}}$, Eva Bartok ${ }^{\mathrm{a}, \mathrm{d}}$, Gunther Hartmann ${ }^{\mathrm{a} *}$ and Marcel

a Institute of Clinical Chemistry and Clinical Pharmacology, University Hospital Bonn, Bonn, Renn ${ }^{\mathrm{a}, \mathrm{e}^{*}}$

7

* denotes shared authorship.

${ }^{\mathrm{b}}$ Department of Radiation Oncology, University Hospital Bonn, Bonn, Germany

${ }^{c}$ Institute of Laboratory Medicine, German Heart Centre, Munich, Germany

${ }^{\mathrm{d}}$ Unit of Experimental Immunology, Department of Biomedical Sciences, Institute of Tropical Medicine, Antwerp, Belgium

${ }^{\mathrm{e}}$ Mildred Scheel School of Oncology, Bonn, University Hospital Bonn, Medical Faculty, D53127, Bonn, Germany

The activation of the innate immune receptor RIG-I is a promising approach in immunooncology and currently under investigation in clinical trials. RIG-I agonists elicit a strong immune activation in both tumor and immune cells and induce both direct and indirect immune cell-mediated tumor cell death which involves tumor-specific cytotoxic T-cell response and type I interferon-driven innate cytotoxic immunity. Besides RIG-I, irradiation is known to induce cytotoxic DNA damage resulting in tumor debulking followed by the induction of tumor-specific immunity. To date, it is unclear whether the molecular antitumor effects of RIG-I and irradiation are additive or even synergize. Here, we investigated the combination of RIG-I activation with radiotherapy in melanoma. We found that low dose Xray irradiation enhanced the extent and immunogenicity of RIG-I mediated tumor cell death in human and murine melanoma cell lines and in the murine B16 melanoma model in vivo. Pathway analysis of transcriptomic data revealed a central role for p53 downstream of the combined treatment, which was corroborated using $\mathrm{p} 53^{-/-} \mathrm{B} 16$ cells. In vivo, the additional effect of irradiation on immune cell activation and inhibition of tumor growth was lost in mice carrying p53-knockout B16 tumors, while the response to RIG-I stimulation in those mice was maintained. Thus, our results identify p53 as pivotal for the synergy of RIG-I with irradiation, resulting in potent induction of immunogenic tumor cell death. Consequently, low dose radiotherapy holds great promise to further improve the efficacy or RIG-I ligands especially in patients with malignant melanoma or other tumors exhibiting a functional p53 pathway. 
80

81

82

83

\section{Introduction}

Recent advances in immunotherapy have significantly prolonged survival for patients with many types of tumors [1]. In addition to immune checkpoint inhibition, targeted stimulation of the innate immune system has become the focus of a number of preclinical and clinical studies $[2,3]$. One particularly promising approach is the specific activation of the cytosolic RNA receptor RIG-I, which is under investigation as a single therapy or in combination with pembrolizumab (NCT03739138) for the treatment of solid tumors.

RIG-I is a cytosolic antiviral receptor that recognizes 5'-tri- or 5'-diphosphate, bluntended double-stranded RNA [4-6]. In addition to its ability to trigger a potent innate cytotoxic immune response, RIG-I stimulation has the ability to directly induce tumor cell death [7,8]. This RIG-I-induced cell death bears the hallmarks of an immunogenic cell death [9], such as HMGB1 release and calreticulin exposure on the cell surface [10-12]. RIG-I stimulation in situ thus possesses features of a cancer vaccine: it can turn a cold tumor into a hot tumor that simultaneously releases tumor antigens and creates a pro-immunogenic environment facilitating the development of tumor-specific cytotoxic T cells $[10,13]$.

Radiation therapy is also a well-known inducer of immunogenic tumor cell death [14]. Irradiated, dying tumor cells have been reported to release pro-inflammatory cytokines including CXCL16 and TNF $\alpha$ [15,16], the cGAS ligand cGAMP [17,18], and alarmins such as HMGB1 and ATP [19-21]. There have also been reports that ionizing radiation (IR) can induce the expression of MHC class I proteins $[22,23]$ and calreticulin $[24,25]$ on the surface of irradiated, dying cells, which promotes recognition and internalization of the cells by phagocytes and subsequent $T$ cell activation. In recent studies, radiation has been combined with immunotherapies such as checkpoint inhibitors in pre-clinical and clinical trials [26]. For example, high-dose $(20 \mathrm{~Gy})$ radiation enhanced the efficacy of antibodies against CTLA4 or PD-L1 in the B16 mouse melanoma model [27] and in a phase I/II trial, fractionated radiotherapy improved the survival of non-small-cell lung cancer patients co-treated with pembrolizumab (anti-PD-1) compared to pembrolizumab alone [28]. However, therapies that combine irradiation and targeted innate immune activation have not yet been widely explored, and there is no information to date about the combination of irradiation and specific activation of RIG-I.

In the current study, we investigated the effect of a combination therapy between the RIG-I ligand 3pRNA and low-dose (2 Gy) irradiation. Irradiation significantly increased RIGI-induced immunogenic cell death in both human and murine melanoma cell lines and tumorcell uptake and activation of dendritic cells. Using an in vivo B16 melanoma model, we observed that cotreatment of 3pRNA with low-dose, tumor-targeted irradiation resulted in increased activation of T- and NK cells in draining lymph nodes and prolonged the overall survival of tumor-bearing animals. Pathway analysis of transcriptomic data revealed a central role for p53 downstream of the combined treatment, which was corroborated using $\mathrm{p} 53^{-/} \mathrm{B} 16$ cells. Here, we found that, while the contribution of RIG-I was independent of p53, the additional effect of irradiation was indeed p53-dependent. Altogether, our study demonstrates that radiotherapy could potentially enhance RIG-I-mediated immunotherapy, especially in patients with tumors with an intact $\mathrm{p} 53$ pathway, such as most malignant melanomas. 


\section{Results}

85 Combined 3pRNA radio-immunotherapy induces immunogenic tumor cell death and tumor

86 cell uptake by dendritic cells as well as activation in vitro

87

88

89

90

91

92

93

94

95

96

97

98

99

100

101

102

103

104

105

106

107

108

109

110

111

112

113

114

115

116

117

118

119

120

121

122

123

124

125

126

127

128

129

130

131

132

133
To investigate whether irradiation combined with RIG-I activation has a synergistic effect on the induction of immunogenic cell death in vitro, we stimulated the murine B16 and human A375 melanoma cell lines with the RIG-I ligand 3pRNA [29] followed by 2 Gy of ionizing radiation (IR) 30 min later. Irradiation significantly increased RIG-I-induced cell death, as measured by Annexin V positive and Annexin V/7AAD double-positive cells (Fig. 1 A-B, suppl. Fig. 1 A) as well as intracellular cleaved caspase 3 levels (suppl. Fig. 1 C). Moreover, RIG-I activation and irradiation significantly lowered the $\mathrm{EC}_{50}$ for the induction of cell death as quantified by Annexin V/7AAD staining, from $987 \mathrm{ng} / \mathrm{ml}$ for $3 p R N A$ alone to $293 \mathrm{ng} / \mathrm{ml}$ of 3pRNA in combination with 2 Gy radiation in murine B16 cells and from $1754 \mathrm{ng} / \mathrm{ml}$ to $333 \mathrm{ng} / \mathrm{ml}$ in human A375 melanoma cells (Fig. 1 C, D, suppl. Fig. 1 D, E). Since higher radiation doses increased cell death on their own but did not further increase RIG-I-induced melanoma cell death (suppl. Fig. 1 F), a radiation dose of 2 Gy was used throughout the rest of the study. Several other human melanoma cell lines (MaMel19, MaMel54, and MaMel48) and A549 lung adenocarcinoma cells also showed increased cell death when RIG-I stimulation was combined with irradiation (Fig. 1 E, F). Notably, this effect could not be recapitulated with the addition of recombinant IFN- $\alpha$ alone (suppl. Fig. 1 B).

Calreticulin exposure on the outer leaflet of the cell membrane induces efferocytosis of dead or dying cells by antigen presenting cells (APCs) and is a hallmark of immunogenic cell death [30]. In agreement with the Annexin V data, calreticulin exposure was also found to be significantly increased when irradiation and RIG-I activation were combined in murine B16 melanoma cells and human A375 cells (Fig. 1 G, H). Surface expression of calreticulin was highest in Annexin V/7AAD double-positive cells, which are known to be in late-stage programmed cell death (suppl. Fig. $1 \mathrm{G}$ ). Interestingly, the expression of MHC-I on murine B16 cells and human A375 melanoma cells was also strongly induced by the combination treatment, most prominently on Annexin V/7AAD negative cells (suppl. Fig. $1 \mathrm{G}, \mathrm{H}, \mathrm{I}$ ). Furthermore, the release of the nuclear protein HMGB1, which serves as a danger-associated molecular pattern (DAMP) and is another characteristic of immunogenic cell death, was induced by RIG-I stimulation in both cell lines and further increased by 2 Gy irradiation in human A375 cells (Fig 1 I, J). RIG-I stimulation, but not 2 Gy irradiation, induced the release of type I interferon in murine B16 melanoma cells and type I and type III interferon in human A375 cells. In murine B16 cells, combination treatment slightly enhanced the secretion of IL6 and TNF $\alpha$ but did not lead to an increase in the release of interferons or the interferonstimulated chemokine CXCL10 (suppl. Fig. 2 A), whereas in human A375 cells, IL6, GMCSF, IL29 (interferon lambda 1) and CXCL10, but not IFN- $\beta$ was enhanced by irradiation when added to RIG-I stimulation (suppl. Fig. 2 B).

To test whether the combination treatment had an impact on tumor-cell uptake by professional antigen-presenting cells and their activation, B16 melanoma cells were treated as before with 3pRNA and irradiation, but then stained with the eFluor780 fixable live/dead dye and co-incubated with bone marrow-derived dendritic cells (BMDCs). BMDCs of wildtype C57BL/6 mice "fed" with B16 cells after combination treatment demonstrated higher levels of eFluor780 dye uptake than after irradiation or RIG-I activation alone. Combination treatment also significantly enhanced the expression of the costimulatory molecule CD86 and the immune cell activation marker CD69 (Fig. $1 \mathrm{~K}$ ).

3pRNA antitumor immunotherapy in vivo is enhanced by low-dose irradiation 
134 Next, we studied combined irradiation and RIG-I activation in vivo. C57BL/6 mice with

135 palpable subcutaneous B16 melanoma were treated with 2 Gy precision irradiation of the

136 tumor area and intratumoral injection of $20 \mu \mathrm{g} 3$ pRNA twice a week. Compared to untreated

137 tumors, both 3pRNA treatment and irradiation alone prolonged the survival of the mice. The

138 combination of irradiation and RIG-I activation resulted in the longest overall survival (Fig. 2

139 A). In tumor-draining lymph nodes analyzed at 16 hours after treatment, NK cells and CD8 ${ }^{+}$

140 T cells showed increased expression of the activation marker CD69 upon RIG-I activation,

141 with highest expression when RIG-I activation and irradiation were combined. In CD4 ${ }^{+} \mathrm{T}$

142 cells, only the combination treatment of RIG-I activation and irradiation induced significant

143 upregulation of CD69 (Fig. 2 B).

144

145

146

147

148 To explore the potential molecular mechanisms of the combination therapy, we performed

149 whole-genome transcriptional analysis with an Affymetrix gene chip on B16.F10 cells six

150 hours after treatment with 3pRNA and irradiation. Upon RIG-I stimulation, we observed a

151 strong change in gene-expression patterns and the robust induction of interferon stimulated

152 genes (ISGs), whereas irradiation primarily induced genes associated with the DNA damage

153 response (Fig 3 A). As expected, a pathway analysis of differentially expressed genes showed

154 that RIG-I stimulation was associated with pathways involved in innate immunity, while

155 irradiation induced genes of the p53 pathway. The p53 pathway was also among the most

156 significantly upregulated pathways in the combination group (Fig. 3 B) and the only

157 differentially regulated pathway between RIG-I activation alone and its combination with

158 irradiation (Fig. 3 C, D). Given the central role of p53 signaling in DNA damage and cell-

159 cycle control, we reasoned that it may also be involved in the synergistic antitumoral effects

160 observed for the combination treatment.

161

162 Combined irradiation and RIG-I activation synergistically induces p53 signaling and

163

164

165

166

167

168

169

170

171

172

173

174

175

176

177

178

179

180

181

182

183

184 prolongs cell-cycle arrest

We then examined the effect of RIG-I activation, irradiation and combination treatment on p53 phosphorylation and signaling. As expected, irradiation induced p53 phosphorylation six hours after treatment, which declined after 24 hours. In contrast, RIG-I activation alone only led to weak p53 phosphorylation and only after 24 hours. However, combination treatment with 3pRNA and irradiation caused B16 cells to retain strong p53 phosphorylation even 24 hours after treatment (Fig. 4 A). Notably, total p53 protein levels at 24 hours were only elevated in 3pRNA-transfected B16 cells (both with and without irradiation). Moreover, these effects were not seen when irradiation was combined with control RNA or IFN $\alpha$. We then analyzed two proteins induced by p53, Puma (Fig. 4 A) and p21(Fig. 4 B). Puma was induced by RIG-I activation and irradiation both at six hours and 24 hours, with the strongest signal in the combination group at 24 hours (Fig. 4 A). p21 was upregulated 24 hours after RIG-I stimulation or irradiation and most strongly in combination, while ATM, an important upstream regulator of p53 activation, was only upregulated by RIG-I stimulation and not further upregulated by combination treatment (Fig. 4 B).

To monitor cell-cycle progression, we stained B16 melanoma cells with propidium iodide six, 12, and 24 hours after 2 Gy irradiation and RIG-I stimulation. Irradiation induced a G2/M cell-cycle arrest after six hours which was already less pronounced after 12 hours and had completely resolved 24 hours post-irradiation (Fig. 4 C). RIG-I stimulation alone, on the other hand, led to a G1/S arrest, which took 24 hours to develop, in line with its slower induction of p53 phosphorylation when compared to irradiation (Fig. 4 A). Like irradiation alone, 
185 combination of irradiation and RIG-I stimulation led to a G2/M arrest after six hours.

186 However, this arrest was maintained even after 24 hours (Fig. 4 C), which was consistent with

187 the time course observed for p53 phosphorylation (Fig. 4 A).

Synergistic effect of irradiation and RIG-I activation is p53 dependent, while the RIG-I effect alone is p53 independent

To test the functional relevance of p53 in combination therapy, we generated polyclonal p53knockout (KO) cells using Crispr/Cas9 genome editing. Polyclonal p53 $3^{-/-} \mathrm{B} 16$ and p53 ${ }^{-1-} \mathrm{A} 375$ melanoma cells showed no basal p53 expression and, as expected, did not upregulate p53 protein at two hours nor the p53 target protein p21 at 24 hours following irradiation (Supp. Fig. 3 A-D). While the amount of cell death induced by 3 pRNA treatment alone was similar between wildtype and knockout cells, the increase upon additional irradiation was largely abolished in the p53 $3^{-/}$cells (Fig. 5 A, B). Correspondingly, no contribution of irradiation to cell death induction was observed in human p53 deficient SK-Mel28 melanoma cells, which carry an endogenous inactivating p53 mutation [31] (Supp. Fig. 3 E). Nevertheless, RIG-I stimulation still induced strong cell death in those SK-Mel28 melanoma cells despite the lack of functional p53 [31] (Supp. Fig. 3 E). Similar to the induction of cell death, the G1/S arrest induced by RIG-I stimulation alone after 24 hours was still present in the p53 KO B16 melanoma cells. Furthermore, the G2/M arrest induced by irradiation after six hours was still detectable, but the prolonged G2/M arrest after 24 and 48 hours with combination treatment was absent in the p53 KO cells (Fig. $5 \mathrm{C}$ ).

Analysis of single phases of the cell cycle revealed that the highest proportion of cells were in G2/M phase arrest after 48 hours, which, at this time point, only occurs after combination treatment in wildtype cells but not p53 deficient cells (Supp. Fig. 4). Moreover, the observed correlation of G2/M cell cycle arrest (Fig 5 B) and caspase 3 activity (Supp. Fig. 4) underscores the close link between cell cycle arrest and cell death.

Calreticulin expression on the cell surface of p53-deficient murine B16 or p53 deficient human A375 melanoma cells was not further enhanced by combining RIG-I stimulation with irradiation (Fig. 5 D, E). Corresponding to the level of cell-surface calreticulin, the effect of irradiation on the uptake of p53 KO B16 melanoma cells was markedly reduced in comparison to wildtype cells. Furthermore, no irradiation-dependent increase in the expression of the activation markers CD86 und CD69 on dendritic cells could be detected when the phagocytosed tumor cells lacked p53 (Fig. 5 F). This shows that all irradiationdependent effects, including cell death, immunogenicity, subsequent uptake of dying cells by DCs, and activation of DCs, are dependent on the expression of p53 in melanoma cells, whereas the effect of RIG-I treatment alone is not affected by the absence of p53.

\section{Synergistic anti-tumor activity of irradiation and RIG-I, but not the effect of RIG-I alone, in} vivo depends on functional p53 in melanoma

In the B16 melanoma model in vivo, both $\mathrm{T}$ cell activation and NK cell activation in the draining lymph node, as measured by upregulation of CD69 on $\mathrm{CD}^{+} \mathrm{T}$ cells, CD4 ${ }^{+} \mathrm{T}$ cells and NK $1.1^{+}$NK cells was significantly enhanced by 3pRNA injection compared to untreated mice. Additional irradiation of the tumor area further enhanced the expression of activation markers on $\mathrm{T}$ cells and NK cells in the draining lymph nodes. This additional irradiationdependent stimulatory effect was lost in mice which were challenged with p53-deficient tumor cells (Fig. 6 A), recapitulating the results obtained for immunogenic cell death and dendritic cell activation in vitro (Fig. 5 and suppl. Fig. 3). Consistent with activation of T cells and NK cells in draining lymph nodes, tumor growth was significantly reduced by RIG-I stimulation in wildtype and p53 KO melanomas, but the significant additional effect of local 
236 tumor irradiation was reduced and no longer statistically significant when mice were 237 challenged with p53 deficient melanoma cells (Fig. 6 B). This further supports the notion that 238 the synergistic effect of combination treatment in vivo is dependent on p53 expression within 239 the tumor cell. Nonetheless, the effectivity of RIG-I immunotherapy itself was independent of 240 the p53 status of the melanoma cells.

241

242

243

244

245

246

247

248

\section{Discussion}

Several studies in different tumor models have demonstrated that intratumoral injection of RIG-I ligands induces an effective anti-tumor immune response [8,32], and this immunotherapeutic strategy is currently being explored in clinical trials (NCT03739138). However, intratumoral injection of RNA ligands remains technically challenging and limited by injection volumes and the concentration of RNA in delivery systems [33].

Here, we found that combination of RIG-I treatment with radiotherapy is a highly promising combinatorial treatment for tumors with intact p53 pathway, such as most malignant melanomas [34]. Localized irradiation of the tumor in a melanoma model in vivo substantially improved therapeutic efficacy of intratumoral RIG-I ligand injections. This enhanced antitumor effect was accompanied by increased activation of $\mathrm{CD}^{+}$and $\mathrm{CD} 8^{+} \mathrm{T}$ cells and of $\mathrm{NK}$ cells in tumor-draining lymph nodes. In vitro, low-dose ionizing irradiation of tumor cells synergistically enhanced RIG-I-mediated induction of immunogenic tumor cell death as characterized by increased cell-surface expression of calreticulin and the release of HMGB1 and of inflammatory chemokines and cytokines. The uptake of such immunogenic cell death material by dendritic cells enhanced their activation status. Molecularly, the synergy of irradiation and RIG-I could be ascribed to distinct effects on the p53 pathway, resulting in a prolonged cell cycle arrest of tumor cells in the G2/M phase, which only occurred if RIG-I and irradiation were combined, leading to subsequent immunogenic cell death. Notably, the p53 pathway was required for synergistic activity in vitro and in vivo but not for the antitumor activity of intratumoral RIG-I ligand treatment as a single treatment.

P53 is one of the most important tumor-suppressor genes. In approximately $50 \%$ of all human tumors, p53 is either mutated or functionally inactive [35] or Mdm2 is overexpressed and downregulates p53 expression [36]. Therefore, the data in our study that demonstrate the p53independence of RIG-I therapy as a monotherapy are encouraging for RIG-I-mediated immunotherapy in general. Based on our results, the combination of RIG-I with radiotherapy should be limited to tumors with an intact p53 pathway. In melanoma the frequency of p53 mutations is only 10 to $19 \%$ [34], suggesting that the combination therapy is well suited for malignant melanoma as a target tumor entity.

It is interesting to note that there is evidence from previous studies that p53 signaling is important to antiviral defense and interferon signaling [37,38]. It has been shown that treatment with IFN- $\beta$ concurrent to irradiation or chemotherapy in mouse embryonic fibroblasts and in human hepatic cancer cells IFN- $\beta$ sensitized the cells for a higher induction of apoptosis [38]. However, in our study, recombinant type I IFN was not a sufficient substitute for RIG-I stimulation since it did not co-trigger enhanced and prolonged p53 phosphorylation or the induction of immunogenic cell death by radiotherapy.

In one study, the combination of irradiation and innate immune activation was studied in lung carcinoma cell lines, where the unspecific antiviral receptor agonist poly(I:C) together with 4 Gy irradiation was demonstrated to enhance the cytotoxic effects of the monotherapies on carcinoma cell lines in a caspase-dependent manner in vitro [39]. However, it should be noted that poly(I:C) activates multiple dsRNA receptors, including PKR, OAS1, ZBP1, TLR3, MDA5, and RIG-I (Bartok and Hartmann, 2020), rendering this rather non- specific immunotherapeutic approach more prone to interindividual variability and immunotoxic side effects. 
287 Another study has demonstrated synergistic inhibition of tumor growth and enhanced 288 induction of long-term immune memory cells in murine mammary and pancreatic carcinoma 289 models using a combination of poly(I:C) injection with transplantation of alpha-emitting 290 radiation seeds into the tumor [40], an experimental treatment approach that is currently tested 291 in clinical trials (e.g., NCT-04377360, NCT-03353077, NCT-03015883). In contrast, in our 292 approach, a clinical linear accelerator has been used, which is standard clinical practice and is 293 therefore directly applicable in routine clinical care.

294 Another interesting aspect of irradiation and immunity is that localized irradiation by itself, 295 independent of additional innate immune activation, has been shown to improve tumor 296 infiltration of adoptively transferred T cells in a pancreatic cancer model [41]. With regard to 297 irradiation intensity, other studies have shown that low doses (2-8 Gy) of irradiation elicit 298 stronger antitumor immunity compared to high doses, especially when given repetitively or 299 when combined with other antitumoral treatments [24,42,43]. In our study, despite the modest 300 antitumoral response induced by 2 Gy irradiation alone, this low dose turned out to be more 301 advantageous at co-activating RIG-I-mediated immunity than higher doses of 5 and 10 Gy.

302 Altogether, our study clearly demonstrates that combining the DNA-damaging treatment 303 radiotherapy with RIG-I innate immune signaling synergistically boosts p53-dependent 304 immunogenic tumor-cell death, further underscoring the rationale for evaluating a localized 305 combination therapy that turns cold into hot tumors as an in situ cancer vaccine [13]. Since 306 melanoma is classically considered a "radioresistant" tumor, our study also provides a new 307 rationale for reevaluating radiotherapy in combination with RIG-I activation for a broad range 308 of oncological indications. Moreover, as with other synergistic treatments, it could potentially 309 allow for a reduction of the individual radiation doses and thus reduce the severe side effects 310 associated with radiotherapy. 


\section{Material \& Methods}

\section{Cell lines}

314 Human A375 and SKmel28 melanoma cells, human lung adenocarcinoma cells A549, murine

315 B16.F10 melanoma cells were cultured in DMEM and human melanoma cells MaMel19,

316 MaMel54, and MaMe148 were cultured in RPMI 1640 both supplemented with 10\% heat-

317 inactivated fetal bovine serum (FCS), $100 \mathrm{IU} / \mathrm{ml}$ penicillin, and $100 \mu \mathrm{g} / \mathrm{ml}$ streptomycin (all

318 from Thermo Fisher Scientific) in a humidified incubator at $37^{\circ} \mathrm{C}$ and $5 \% \mathrm{CO}_{2}$. A375 cells

319 were kindly provided by Michael Hölzel (University Hospital Bonn, Germany) and

320 MaMel19, MaMel54 and MaMel48 were kindly provided by Jennifer Landsberg (University

321 Hospital Bonn, Germany) and Dirk Schadendorfer (University Hospital Essen, Germany).

322 B16 and SKmel28 were purchased from ATCC. Identity of human cell lines was confirmed

323 by short-tandem-repeat (STR) profiling (Eurofins). Cells were checked monthly for

324 mycoplasma infection by testing the supernatant with the reporter cell line of the Mycoplasma

325 Detection Kit "PlasmoTest" from Invivogen.

\section{Oligonucleotides, reagents and chemicals}

5'-triphosphorylated double-stranded RNA (3pRNA) were in vitro transcribed (IVT) from a DNA templateby using the phage $\mathrm{T} 7$ polymerase from the Transcript Aid T7 high-yield Transcription Kit (Fermentas) as described previously [29]. Inert $\mathrm{AC}_{20}$ control RNA (5'CACAACAAACCAAACAACCA-3') was obtained from Biomers. Murine IFN $\alpha$ was purchased from BioLegend. The MDM2 inhibitor AMG232 was purchased from MedChemExpress.

\section{Oligonucleotide-transfection of tumor cells}

335 Cells were seeded at a defined cell number the day before transfection and cultured overnight at $37^{\circ} \mathrm{C}$ and $5 \% \quad \mathrm{CO}_{2}$ in an incubator to ensure proper attachment. Lipofectamine 2000 (Invitrogen) and OptiMem (Thermo Fisher Scientific) were used according to the manufacturer's protocol to transfect control $\mathrm{AC}_{20}$ RNA or stimulatory $3 \mathrm{pRNA}$ at the indicated concentrations.

\section{Irradiation of tumor cells}

Cells were irradiated with high-energy photons $(150 \mathrm{keV})$ of $2 \mathrm{~Gy}$ generated by a biological irradiator (RS-2000, Rad Source Technologies).

\section{DC melanoma uptake}

Bone-marrow derived dendritic cells were generated as described previously [44]. B16 melanoma cells were stimulated as indicated. After $48 \mathrm{~h}$ melanoma cells were stained with eFluor780 fixable viability dye (eBioscience, 1:2000 in PBS) for $30 \mathrm{~min}$ on ice. Excess dye was washed away by the addition of DMEM supplemented with $10 \%$ FCS. Stained melanoma cells $(25000)$ were then cocultured with $100000 \mathrm{bmDCs}$ overnight at $37^{\circ} \mathrm{C}$ and $5 \% \mathrm{CO}_{2}$ in a 96well plate. The next day, DCs were detached by adding $2 \mathrm{mM}$ EDTA/PBS and analysed by flow cytometry.

\section{Generation of polyclonal p53 knockout (KO) cell lines by using CRISPR/Cas9}

354 The CRISPR target site for murine p53 (single guide (sg) RNA: 5'355 CTGAGCCAGGAGACATTTTC-3') was already cloned into a px330 plasmid (px330-U6356 Chimeric_BB-CBh-hSpCas9, Addgene plasmid \#42230) and for human p53 (sgRNA: 5'357 GCATCTTATCCGAGTGGA-3') was already cloned into a px459 plasmid (pSpCas9(BB)358 2A-Puro (px459) V2.0 (Addgene plasmid \#62988)) and kindly provided by Daniel Hinze 359 from the lab of Michael Hölzel. B16 and A375 cells were seeded at a density of $5 \times 10^{4}$ cells 360 per well into a 12-well plate the day before transfection with $2 \mu \mathrm{g}$ of the CRISPR/Cas9 
361 plasmid using Lipofectamin 2000. After three days of incubation at $37^{\circ} \mathrm{C}$, the transfected cells

362 were seeded out again into 12 -well plates at a density of $5 \times 10^{3}$ cells per well. One day later 10

$363 \mu \mathrm{M}$ of the MDM2 inhibitor AMG232 was added to the culture medium for five days to

364 positively select p53 deficient cells.

\section{Gene-expression analysis with microarray}

366 B16.F10 cells were transfected with $50 \mathrm{ng} / \mathrm{ml} 3 \mathrm{pRNA}$ or $\mathrm{AC}_{20}$ control RNA and irradiated 367 with 2 Gy or not for $6 \mathrm{~h}$. RNA was isolated with the RNeasy Mini Kit (Qiagen) according to 368 the manufacture's instructions. The extracted RNA was further processed using an Clariom S 369 Mouse Genchip (Thermo Fisher) at the LIFE \& BRAIN Genomics Service Center Bonn.

\section{Western blot analysis}

371 Total cell protein extraction was done as described previously [45]. 30-50 $\mu \mathrm{g}$ of protein was 372 mixed with an equal amount of 2x Laemmli buffer (200 mM Tris/HCl pH 6.8, 4\% SDS, $20 \%$ 373 glycerol, $200 \mathrm{mM}$ DTT), denatured at $95^{\circ} \mathrm{C}$ for $5 \mathrm{~min}$, separated by SDS gel electrophoresis 374 (30 mA per gel, $1.5 \mathrm{~h}$ ), and transferred onto a nitrocellulose membrane (GE Healthcare, 0.45 $375 \mu \mathrm{m}$ pore size of the membrane). Proteins were transferred using $450 \mathrm{~mA}$ for $1.5 \mathrm{~h}$. The 376 membranes were blocked with 5\% non-fat dry milk in TBST buffer (150 mM NaCl, $20 \mathrm{mM}$ 377 Tris, $0.1 \%$ Tween 20, $\mathrm{pH} 7.6$ ) for $1 \mathrm{~h}$ at room temerature (RT) and incubated with the 378 respective primary antibodies at $4^{\circ} \mathrm{C}$ overnight (anti-phospho-p53 (Ser15), anti-p53, antipuma, anti-p21 (all 1:1000, Cell Signaling);). HRP-coupled secondary antibodies, anti-rabbit and anti-mouse (Cell Signaling), were used 1:5000 or IRDye800 coupled anti-rabbit and antimouse (Li-cor Bioscience) antibodies were used 1:10,000 in 5\% milk/TBST and incubated for $1 \mathrm{~h}$ at RT. Anti-actin-HRP antibody (Santa Cruz) diluted 1:5000 in 5\% milk/ TBST or mouse/rabbit anti- 3 -actin ( $\mathrm{Li}$-cor Bioscience) diluted 1:10,000 was used to detect actin as a loading control. Protein bands were detected by using chemiluminescence of an ECL westernblotting substrate (Thermo Scientific) or by near-infrared fluorescence with the Odyssey Fc (Li-cor Biosciences).

\section{Enzyme-linked immunosorbent assay (ELISA)}

To determine concentrations of HMGB1, the supernatants were collected $24 \mathrm{~h}$ after transfection and irradiation of tumor cells and the HMGB1 ELISA Kit from IBL International was used according to the manufacturer's protocol.

\section{Flow cytometry}

Cells of interest were harvested with trypsin and washed with PBS. For staining of surface proteins, fluorochrome-conjugated monoclonal antibodies were diluted 1:200 in FACS buffer 396 (1x PBS containing 10\% FCS, 2 mM EDTA and $0.05 \%$ sodium azide) and incubated with the 397 cells 15-20 min on ice or RT. Antibodies used: APC-Cy7 or BV510 anti-CD4, PerCP-Cy5.5 398 or BV421 anti-CD8, PerCP anti-CD45, BV421 anti-CD11c, Alexa-Fluor-488 or BV510 anti399 CD69, BV785 anti-CD86, BV785, BV510 anti-MHC-I (Hk2b), FITC anti-I-A/E (all 400 BioLegend), FITC anti-CD11c, APC anti-MHC-I (Hk2b), PE or BV650 anti-NK1.1 (all 401 eBioscience), BUV737 anti-CD4, BUV395 anti-CD8, BUV395 anti-CD11b, FITC anti-HLA 402 ABC (all BD Bioscience), Alexa-488 anti-Calreticulin (Cell Signaling Technology, 1:100 403 instead of 1:200).

For in vivo studies, the tissue was digested with $1 \mathrm{mg} / \mathrm{ml}$ collagenase D in PBS with $5 \%$ FCS for $20 \mathrm{~min}$ at $37^{\circ} \mathrm{C}$ and afterwards passed through a $70 \mu \mathrm{m}$ cell strainer with sterile PBS. Cells were afterwards stained with Zombie UV fixable viability stain (1:500 in PBS, 408 from eBioscience, 1:200 in FACS buffer) for 15 min on ice. Surface staining was performed 409 as described above. 
410

411

412

413

414

415

416

417

418

419

420

421

422

423

424

425

426

427

428

429

430

431

432

433

434

435

436

437

438

439

440

441

442

443

444

445

446

447

448

449

450

451

452

453

454

455

456

457

Intracellular staining of activated, cleaved caspase-3 was analyzed using a rabbit anticleaved caspase-3 monoclonal antibody (1:500, Cell Signaling Technology) followed by a second staining with FITC-anti-rabbit IgG (1:200, BioLegend). Both antibodies were diluted in FACS buffer supplemented with $0.5 \%$ saponin.

Fluorescence intensities for all of the flow cytometry-based assays were measured with the LSRFortessa flow cytometer (BD Biosciences), or with the Attune NxT Flow Cytometer (Thermo Fisher).

\section{Quantification of apoptotic cell death}

Cells were stained with anti-Annexin V-Alexa 647 antibody or anti-Annexin V-Pacific Blue antibody (both 1:30, BioLegend) in Annexin binding buffer (10 mM HEPES, pH 7.4; 140 $\mathrm{mM} \mathrm{NaCl} ; 2.5 \mathrm{mM} \mathrm{CaCl}_{2}$ ) and incubated at RT for $20 \mathrm{~min}$ in the dark. Cells were washed and resuspended in $200 \mu \mathrm{l} 1 \mathrm{x}$ binding buffer. $5 \mu \mathrm{l}$ of 7 -amino-actinomycin D (7AAD, $50 \mu \mathrm{g} / \mathrm{ml}$ working solution in PBS, Thermo Fisher Scientific) was added to the stained cells 5-10 min before measurement.

\section{Multiplex cytokine assay}

Multiplex flow-cytometric cytokine detection was performed on cell-culture supernatants collected $24 \mathrm{~h}$ after 3pRNA transfection and irradiation. Cytokine levels were measured using human and mouse LEGENDplex bead-based multi-analyte flow assay kits as described in the manufacturer's manual. However, the assay was performed in a 384 well plate and the volumes adjusted accordingly.

\section{Cell-cycle-phase analysis}

Anaylsis of the cell-cycle phases was performed on cells that were fixed and permeabilized with $70 \%$ ethanol for one hour at RT. Cells were incubated for $30 \mathrm{~min}$ at RT with $10 \mu \mathrm{g} / \mathrm{ml}$ propidium iodide (PI) and $100 \mu \mathrm{g} / \mathrm{ml}$ RNase A in FACS buffer, and directly analyzed by flow cytometry. For simultaneous staining of activated caspase 3, the cultivation medium of cells seeded in 96-well plates was exchanged for $50 \mu \mathrm{l} /$ well of staining solution, containing CellEvent Caspase3/7 Green ReadyProbes, according to the manufacturer's protocol, and 100 $\mu \mathrm{g} / \mathrm{ml}$ Hoechst 33342 (both Thermo Fisher Scientific) and incubated for $30-60 \mathrm{~min}$ at $37^{\circ} \mathrm{C}$. The cells were then detached and analyzed by flow cytometry.

\section{In vivo studies with mice}

Female C57BL/6 mice were obtained from Janvier and used at 8-12 weeks of age. The animals were housed in individually ventilated cages (IVC) in the House of Experimental Therapy (HET) at the University Hospital Bonn. All experiments were approved by local- and regional animal ethics committees. Mice were injected with $1 \times 10^{5}$ B16.F10 cells in $100 \mu \mathrm{l}$ sterile PBS subcutaneously into the right flank of the back. When the tumors reached a diameter of 3-4 mm, the tumors were injected with $20 \mu \mathrm{g} 3 \mathrm{pRNA}$ or $\mathrm{AC}_{21}$ single-stranded control RNA complexed with JetPEI (Polyplus) according to the manufactorers protocol and afterwards locally irradiated with a single dose of 2 Gy. For local irradiation, the mice were narcotized and positioned in the treatment beam. The tumors were stereotactically irradiated with adapted field size in a range between $1-2 \mathrm{~cm}$ using a linear accelerator with a $6 \mathrm{MeV}$ beam (TrueBeam STx, Varian and Mevatron MD, Siemens). The mice were surrounded by water-equivalent RW3 sheets (PTW, Freiburg) and placed in the depth-plane Dmax (15 mm) of the $6 \mathrm{MeV}$-Beam. For the survival studies, treatment of the tumor with 3 pRNA/AC 20 RNA was repeated twice a week and tumor size was measured daily until the tumors reached a diameter of $10 \mathrm{~mm}$.

\section{Statistical analysis}


458 If not indicated otherwise, data are represented as the mean +/- SEM of at least three 459 experiments that were run with two replicates per sample and a statistical analysis of the 460 difference between groups using one or two-way ANOVA, as appropiate, calculated with 461 GraphPad Prism 8. * $(\mathrm{P}<0.05)$, ** $(\mathrm{P}<0.01)$, *** $(\mathrm{P}<0.001)$, **** $(\mathrm{P}<0.0001)$, ns: not 462 significant.

463

464 Declarations

465 Ethics approval and consent to participate

466

467 All animal experiments were approved by the local authorities (LANUV NRW).

468

469

\section{Funding}

470 This study was funded by the Deutsche Forschungsgemeinschaft (DFG, German 471 Research Foundation) under Germany s Excellence Strategy EXC2151 390873048 of 472 which E.B., G.H., and M.S. are members. It was also supported by the Deutsche 473 Forschungsgemeinschaft (DFG, German Research Foundation) Project-ID 369799452 474 TRR237 to E.B., G.H., and M.S, SFB670 to E.B., G.H., and M.S., SFB704 to G.H., GRK 2168 to 475 EB and MS and and DFG SCHL1930/1-2. M.R. is funded by the Deutsche Krebshilfe 476 through a Mildred Scheel Nachwuchszentrum Grant (Grant number 70113307). SL was 477 initially funded by a PhD Scholarship from Bayer Pharma AG (Project number 478 40860128)

\section{Authors' contributions}

480 Silke Lambing: formal analysis, investigation, writing -original draft, writing -review \& 481 editing, visualization,

482 Stefan Holdenrieder: conceptualization, methodology, resources,

483 Patrick Müller: investigation,

484 Christian Hagen: investigation,

485 Stephan Garbe: methodology, resources, writing review \& editing,

486 Martin Schlee: methodology, resources

487 Jasper G. van den Boorn: investigation, methodology, supervision, project administration

488 Eva Bartok: formal analysis, methodology, supervision, project administration, writing 489 original draft, writing -review \& editing, visualization

490 Gunther Hartmann: conceptualization, funding acquisition, methodology, project 491 administration, resources, supervision, visualization, writing -original draft, writing -review 492 \& editing

493 Marcel Renn: formal analysis, investigation, methodology, project administration, 494 supervision, writing -original draft, writing -review \& editing, visualization 
497 We thank Meghan Campbell for her critical reading of this manuscript. We thank Daniel

498 Hinze for providing us with CRISPR gRNA/Cas9 plasmids targeting p53. We thank Jennifer

499 Landsberg for her helpful discussion of the project.

\section{Conflict of interest}

501 M.S and G.H. are inventors on a patent covering synthetic RIG-I ligand. MR and GH were

502 co-founders of Rigontec GmbH.

503

504

505

506

5071 Esfahani K, Roudaia L, Buhlaiga N, et al. A review of cancer immunotherapy: From 508 the past, to the present, to the future. Current Oncology 2020;27:87-97.

509 doi:10.3747/co.27.5223

5102 Bai L, Li W, Zheng W, et al. Promising targets based on pattern recognition

511 receptors for cancer immunotherapy. Pharmacological Research

512 2020;159:105017. doi:10.1016/j.phrs.2020.105017

5133 Junt $\mathrm{T}$, Barchet $\mathrm{W}$. Translating nucleic acid-sensing pathways into therapies.

$514 \quad$ Nature Reviews Immunology. 2015;15:529-44. doi:10.1038/nri3875

5154 Goubau D, Schlee M, Deddouche S, et al. Antiviral immunity via RIG-I-mediated

516 recognition of RNA bearing 50-diphosphates. Nature 2014;514:372-5.

517 doi:10.1038/nature 13590

5185 Hornung V, Ellegast J, Kim S, et al. 5'-Triphosphate RNA Is the Ligand for RIG-I.

$519 \quad$ Science 2006;314:994-7. doi:10.1126/science.1132505

5206 Schlee M, Roth A, Hornung V, et al. Recognition of 5 [ Triphosphate by RIG-I

$521 \quad$ Helicase Requires Short Blunt Double-Stranded RNA as Contained in Panhandle of

522

523 Negative-Strand Virus. Immunity 2009;31:25-34.

5247 Besch R, Poeck H, Hohenauer T, et al. Proapoptotic signaling induced by RIG-I and 525 MDA-5 results in type I interferon-independent apoptosis in human melanoma $526 \quad$ cells. 2009;119. doi:10.1172/JCI37155.The

5278 Poeck H, Besch R, Maihoefer C, et al. 50]-triphosphate-siRNA: turning gene 528 silencing and Rig-I activation against melanoma. Nature Medicine 2008;14:1256529 63. doi: $10.1038 / \mathrm{nm} .1887$

5309 Kroemer G, Galluzzi L, Kepp 0, et al. Immunogenic Cell Death in Cancer Therapy. Annual Review of Immunology 2013;31:51-72. doi:10.1146/annurev-immunol032712-100008

10 Bek S, Stritzke F, Wintges A, et al. Targeting intrinsic RIG-I signaling turns melanoma cells into type I interferon-releasing cellular antitumor vaccines. OncoImmunology 2019;8:1-9. doi:10.1080/2162402X.2019.1570779 
538 dendritic cell activation. Cancer Immunology, Immunotherapy 2019;68:1479-92.

539 doi:10.1007/s00262-019-02380-2

54012 Duewell P, Steger a, Lohr H, et al. RIG-I-like helicases induce immunogenic cell 541 death of pancreatic cancer cells and sensitize tumors toward killing by CD8(+) T

cells. Cell death and differentiation 2014;21:1-13. doi:10.1038/cdd.2014.96

54313 van den Boorn JG, Hartmann G. Turning tumors into vaccines: co-opting the innate

544

545 immune system. Immunity 2013;39:27-37. doi:10.1016/j.immuni.2013.07.011

14 Baskar R, Lee KA, Yeo R, et al. Cancer and Radiation Therapy: Current Advances and Future Directions. International Journal of Medical Sciences 2012;9:193-9. doi:10.7150/ijms.3635

548

15 Hallahan DE, Spriggs DR, Beckett MA, et al. Increased tumor necrosis factor alpha

549

550

551

552

553

554

555 mRNA after cellular exposure to ionizing radiation. Proceedings of the National Academy of Sciences of the United States of America 1989;86:101047.http://www.ncbi.nlm.nih.gov/pmc/articles/PMC298653/

16 Matsumura S, Wang B, Kawashima N, et al. Radiation-Induced CXCL16 Release by Breast Cancer Cells Attracts Effector T Cells. The Journal of Immunology 2008;181:3099 LP 3107.http://www.jimmunol.org/content/181/5/3099.abstract

Marcus A, Mao AJ, Lensink-Vasan M, et al. Tumor-Derived cGAMP Triggers a

557

558

559 STING-Mediated Interferon Response in Non-tumor Cells to Activate the NK Cell Response. Immunity 2018;49:754-763.e4. doi:10.1016/j.immuni.2018.09.016

560

561

562

563

Schadt L, Sparano C, Schweiger NA, et al. Cancer-Cell-Intrinsic cGAS Expression

564

565 Mediates Tumor Immunogenicity. Cell Reports 2019;29:1236-1248.e7.

566

567 doi:10.1016/j.celrep.2019.09.065

Apetoh L, Ghiringhelli F, Tesniere A, et al. Toll-like receptor 4-dependent contribution of the immune system to anticancer chemotherapy and radiotherapy. Nature Medicine 2007;13:1050-9. doi:10.1038/nm1622

573

574

21 Ohshima Y, Tsukimoto M, Takenouchi T, et al. $\gamma$-Irradiation induces P2X7 receptor-dependent ATP release from B16 melanoma cells. Biochimica et Biophysica Acta - General Subjects 2010;1800:40-6. doi:10.1016/j.bbagen.2009.10.008

575

576

577

Golden EB, Frances D, Pellicciotta I, et al. Radiation fosters dose-dependent and chemotherapy-induced immunogenic cell death. OncoImmunology 2014;3. doi:10.4161/onci.28518

578

Hauser SH, Calorini L, Wazer DE, et al. Radiation-enhanced expression of major histocompatibility complex class I antigen H-2Db in B16 melanoma cells. Cancer Res 1993;53:1952-5.

23 Reits E a, Hodge JW, Herberts $\mathrm{C}$ a, et al. Radiation modulates the peptide repertoire, enhances $\mathrm{MHC}$ class I expression, and induces successful antitumor immunotherapy. The Journal of experimental medicine 2006;203:1259-71. doi:10.1084/jem.20052494 
57924 Gameiro SR, Jammeh ML, Wattenberg MM, et al. Radiation-induced immunogenic

580

581

582

583

584

585

586

587

588

589

590

591

592

593

594

595

596

597

598

599

600

601

602

603

604

605

606

607

608

609

610

611

612

613

614

615

616

617

618

modulation of tumor enhances antigen processing and calreticulin exposure, resulting in enhanced T-cell killing. Oncotarget 2014;5:403-16.

doi:10.18632/oncotarget.1719

25 Obeid M, Panaretakis T, Joza N, et al. Calreticulin exposure is required for the immunogenicity of $\gamma$-irradiation and UVC light-induced apoptosis. Cell Death and Differentiation. 2007;14:1848-50. doi:10.1038/sj.cdd.4402201

26 Kang J, Demaria S, Formenti S. Current clinical trials testing the combination of immunotherapy with radiotherapy. Journal for ImmunoTherapy of Cancer 2016;4. doi:10.1186/s40425-016-0156-7

27 Twyman-Saint Victor C, Rech AJ, Maity A, et al. Radiation and dual checkpoint blockade activate non-redundant immune mechanisms in cancer. Nature 2015;520:373-7. doi:10.1038/nature14292

28 Theelen WSME, Chen D, Verma V, et al. Pembrolizumab with or without radiotherapy for metastatic non-small-cell lung cancer: a pooled analysis of two randomised trials. The Lancet Respiratory Medicine 2021;9:467-75. doi:10.1016/S2213-2600(20)30391-X

29 Goldeck M, Schlee M, Hartmann G, et al. Enzymatic Synthesis and Purification of a Defined RIG-I Ligand. In: Anders HJ, Migliorini A, eds. Innate DNA and RNA Recognition. Methods in Molecular Biology (Methods and Protocols). Humana Press, New York, NY 2014. 15-25. doi:https://doi.org/10.1007/978-1-4939-0882-0_2

30 Obeid M, Tesniere A, Ghiringhelli F, et al. Calreticulin exposure dictates the immunogenicity of cancer cell death. Nature medicine 2007;13:54-61. doi:10.1038/nm1523

31 Haluska FG, Wu H, Haluska FS, et al. Genetic Alterations in Signaling Pathways in Melanoma. Published Online First: 2006. doi:10.1158/1078-0432.CCR-05-2518

32 Heidegger S, Kreppel D, Bscheider M, et al. RIG-I activating immunostimulatory RNA boosts the efficacy of anticancer vaccines and synergizes with immune checkpoint blockade. EBioMedicine 2019;41:146-55.

doi:10.1016/j.ebiom.2019.02.056

33 Whitehead KA, Langer R, Anderson DG. Knocking down barriers: Advances in siRNA delivery. Nature Reviews Drug Discovery 2009;8:129-38.

doi:10.1038/NRD2742

34 Box NF, Vukmer T0, Terzian T. Targeting p53 in melanoma. Pigment Cell \& Melanoma Research 2014;27:8-10. doi:10.1111/pcmr.12180

35 Olivier M, Hollstein M, Hainaut P. TP53 mutations in human cancers: origins, consequences, and clinical use. Cold Spring Harbor perspectives in biology 2010;2:a001008. doi:10.1101/cshperspect.a001008

36 Momand J, Jung D, Wilczynski S, et al. The MDM2 gene amplification database. Nucleic Acids Research 1998;26:3453-9. doi:10.1093/nar/26.15.3453 
61937 Porta C, Hadj-Slimane R, Nejmeddine M, et al. Interferons $\alpha$ and $\gamma$ induce p53-

620

621

622

623

624

625

626

627

628

629

630

631

632

633

634

635

636

637

638

639

640

641

642

643

644

645

646

647

648

649

dependent and p53-independent apoptosis, respectively. Oncogene 2005;24:60515. doi:10.1038/sj.onc. 1208204

38 Takaoka A, Hayakawa S, Yanai $H$, et al. Integration of interferon- $\alpha / \beta$ signalling to p53 responses in tumour suppression and antiviral defence. Nature 2003;424:516-23. doi:10.1038/nature01850

39 Yoshino H, Iwabuchi M, Kazama Y, et al. Effects of retinoic acid-inducible gene-ilike receptors activations and ionizing radiation cotreatment on cytotoxicity against human non-small cell lung cancer in vitro. Oncology Letters 2018;15:4697-705. doi:10.3892/ol.2018.7867

40 Domankevich V, Efrati M, Schmidt M, et al. RIG-1-Like Receptor Activation Synergizes With Intratumoral Alpha Radiation to Induce Pancreatic Tumor Rejection, Triple-Negative Breast Metastases Clearance, and Antitumor Immune Memory in Mice. Frontiers in Oncology 2020;10. doi:10.3389/fonc.2020.00990

41 Klug F, Prakash H, Huber PE, et al. Low-Dose Irradiation Programs Macrophage Differentiation to an iNOS+/M1 Phenotype that Orchestrates Effective T Cell Immunotherapy. Cancer Cell 2013;24:589-602. doi:10.1016/j.ccr.2013.09.014

42 Vanpouille-Box C, Alard A, Aryankalayil MJ, et al. DNA exonuclease Trex1 regulates radiotherapy-induced tumour immunogenicity. Nature communications 2017;8:15618. doi:10.1038/ncomms15618

43 Chen J, Harding SM, Natesan R, et al. Cell Cycle Checkpoints Cooperate to Suppress DNA- and RNA-Associated Molecular Pattern Recognition and Anti-Tumor Immune Responses. Cell Reports 2020;32. doi:10.1016/j.celrep.2020.108080

44 Gehrke N, Mertens C, Zillinger T, et al. Oxidative damage of dna confers resistance to cytosolic nuclease trex1 degradation and potentiates STING-dependent immune sensing. Immunity 2013;39:482-95. doi:10.1016/j.immuni.2013.08.004

45 Engel C, Brügmann G, Lambing S, et al. RIG-I Resists Hypoxia-Induced Immunosuppression and Dedifferentiation. Cancer Immunology Research 2017;5:455-67. doi:10.1158/2326-6066.CIR-16-0129-T 
bioRxiv preprint doi: https://doi.org/10.1101/2021.10.16.464638; this version posted October 16, 2021. The copyright holder for this preprint (which was not certified by peer review) is the author/funder, who has granted bioRxiv a license to display the preprint in perpetuity. It is made available under aCC-BY-NC-ND 4.0 International license.

A

B16:
cell death induction after $48 \mathrm{~h}$

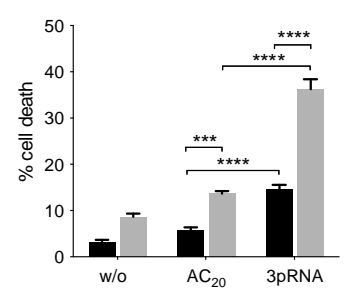

E

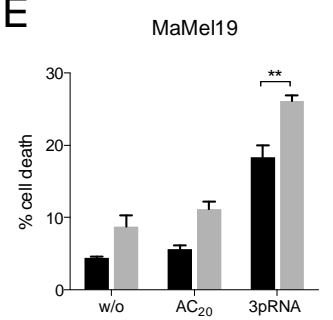

G

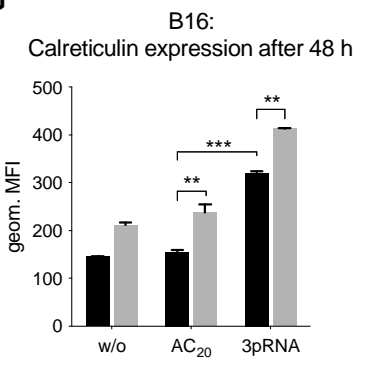

B

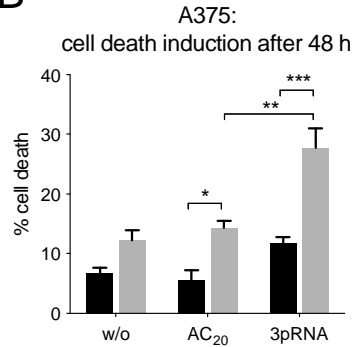

C

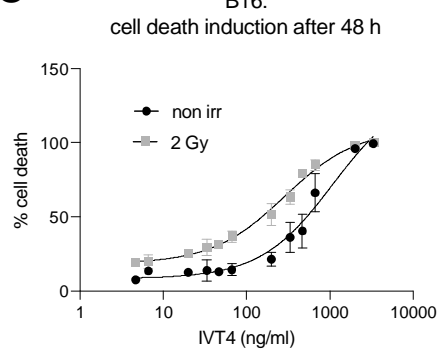

D A375:

cell death induction after $48 \mathrm{~h}$

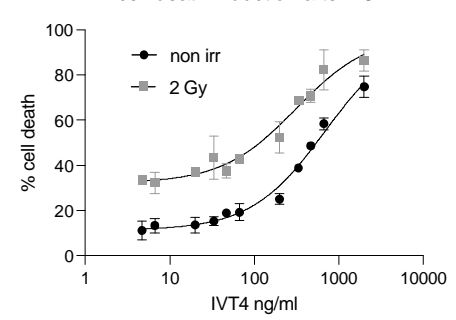

F human lung

adenocarcinoma A549
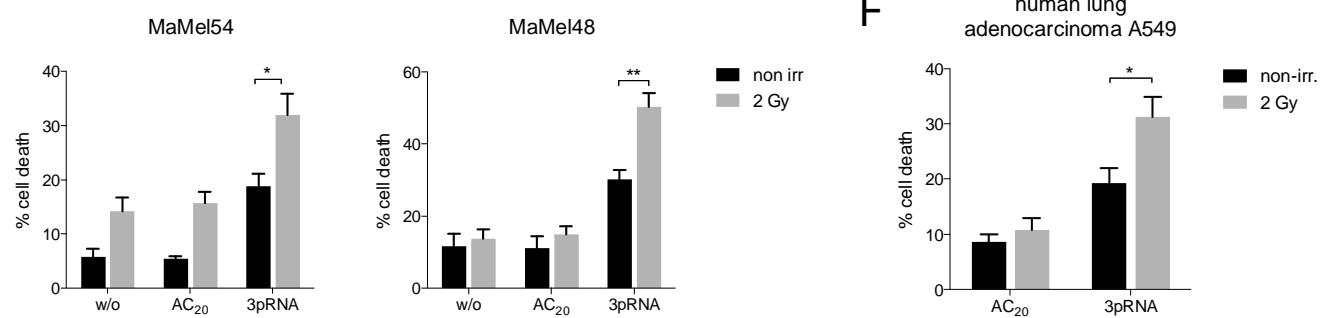

$\mathrm{H}$

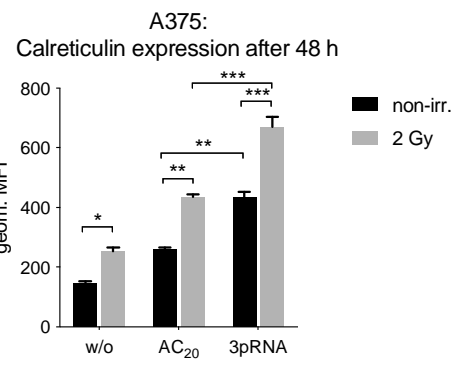

I B16:
HMGB1 in supernatant after $24 \mathrm{~h}$

J $A 375$ :
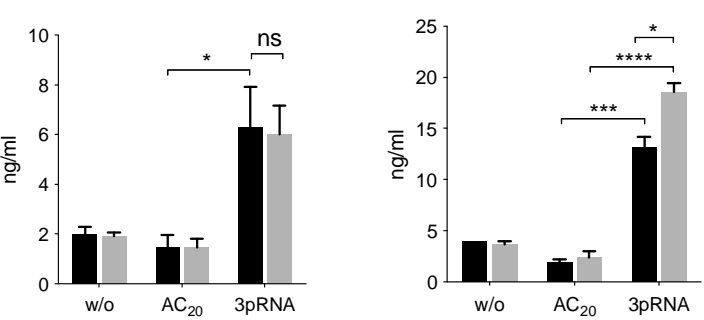

K
$\mathrm{B} 16+\begin{aligned} & 3 p R N A \\ & +/-2 \text { Gy }\end{aligned}$
$48 \mathrm{~h}$
Live/Dead
staining
addition
to DCs
$\stackrel{24 \mathrm{~h}}{\longrightarrow} \underset{\text { analysis }}{\text { FACS }}$

DC efferocytosis after $24 \mathrm{~h}$ coculture

DC CD86 upregulation after $24 \mathrm{~h}$ coculture

DC CD69 upregulation after $24 \mathrm{~h}$ coculture
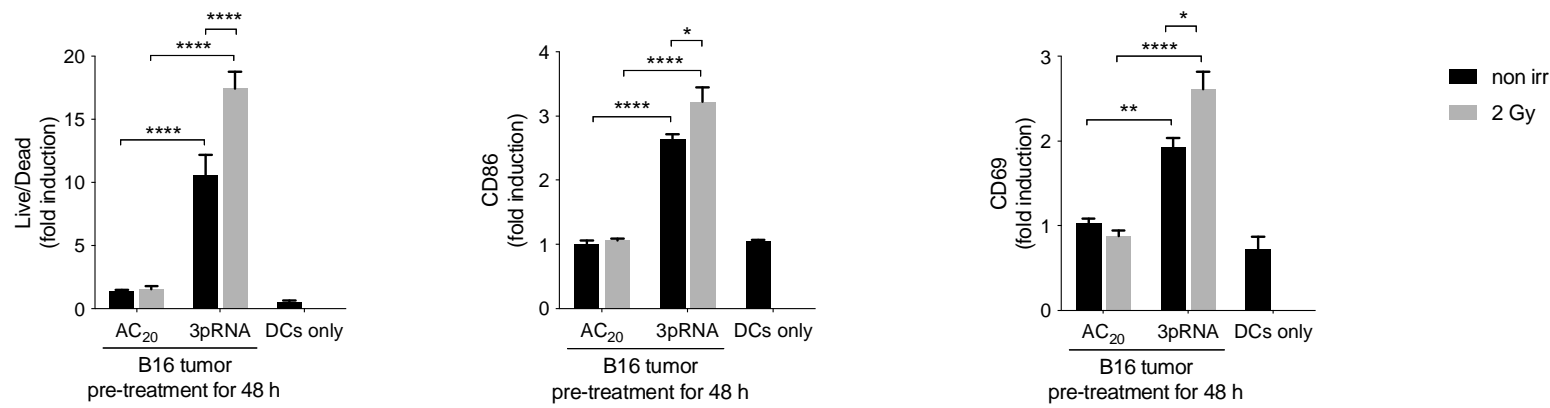

Figure 1: Irradiation enhances 3pRNA-induced immunogenic cell death in melanoma cells, as well as uptake by and co-stimulation of dendritic cells. Murine B16 and human A375 melanoma cells were transfected with $50 \mathrm{ng} / \mathrm{ml}$ $3 p R N A$ or $A C_{20}$ control RNA followed by 2 Gy irradiation. (A, B) $48 \mathrm{~h}$ later, apoptosis was measured in B16 (A) and A375 (B) cels by using Annexin V/7AAD detection by flow cytometry. (C, D) Cell death detection was repeated as described in $(A, B)$. The dose of 3pRNA ligand was titrated in B16 (C) and A375 (D) cells to determine the $E_{50}$ value with and without 2 Gy, calculated by Graphpad Prism. Exemplarily titration curve shown. (E) Different human melanoma cell lines were transfected with $50 \mathrm{ng} / \mathrm{ml}$ (MaMel19) or $200 \mathrm{ng} / \mathrm{ml}$ (MaMel54, MaMel48) 3pRNA and (F) human lung carcinoma cell line A549 was transfected with $50 \mathrm{ng} / \mathrm{ml} 3$ pRNA. Cells were additionally irradiated with 0 or 2 Gy. Induction of cell death was quantified $48 \mathrm{~h}$ later using Annexin V/7AAD staining and flow cytometry. (G - J) Melanoma cells were transfected with 50 $\mathrm{ng} / \mathrm{ml}$ 3pRNA and irradiated with 2 Gy. $(\mathrm{G}, \mathrm{H})$ After $48 \mathrm{~h}$, expression of calreticulin on the cell surface was measured by flow cytometry or (I, J) after $24 \mathrm{~h}, \mathrm{HMGB} 1$ concentration in the supernatant was measured by ELISA. (K) B16 cells were treated with $200 \mathrm{ng} / \mathrm{ml} 3 \mathrm{pRNA}$ and 2 Gy for $48 \mathrm{~h}$, stained with fixable viability stain, and cocultured with bone-marrowderived DCs from wildtype BL/6 mice for $24 \mathrm{~h}$. DC tumor-cell uptake and activation was measured by flow cytometry. \% cell death was plotted as the sum of Annexin $\mathrm{V}^{+}$, Annexin $\mathrm{V} / 7 \mathrm{AAD} \mathrm{D}^{+}$, and $7 A A D^{+}$populations divided by the total number of cells. A, B, E, F, K: data are shown as mean and SEM of $n=3$ and I, J: $n=2$ independent experiments. C, D, G, H: Representative with mean and $S D$ of $n=3$ independent experiments with similar results. ${ }^{*} p<0,05 ;{ }^{* *} p<0,01 ;{ }^{* * *} p<0,001$; ${ }^{* * * *} p<0.0001$. 2-way ANOVA. w/o: untreated, $A_{20}$ : control RNA, 3pRNA: 5'-triphosphate RNA, non-irr: non-irradiated. 
bioRxiv preprint doi: https://doi.org/10.1101/2021.10.16.464638; this version posted October 16, 2021. The copyright holder for this preprint (which was not certified by peer review) is the author/funder, who has granted bioRxiv a license to display the preprint in perpetuity. It is made available under aCC-BY-NC-ND 4.0 International license.

\section{A}

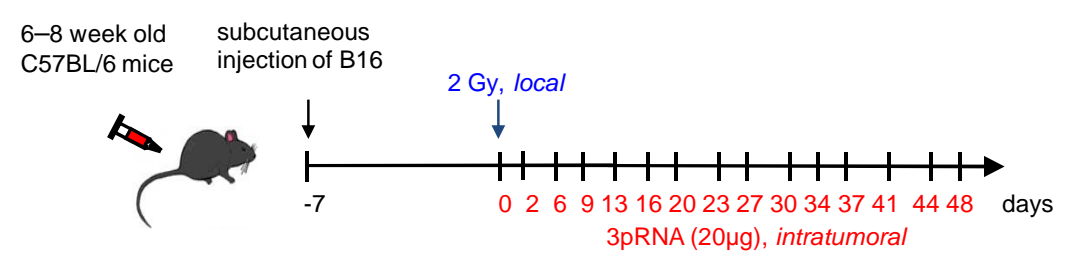

Kaplan-Meier survival curve

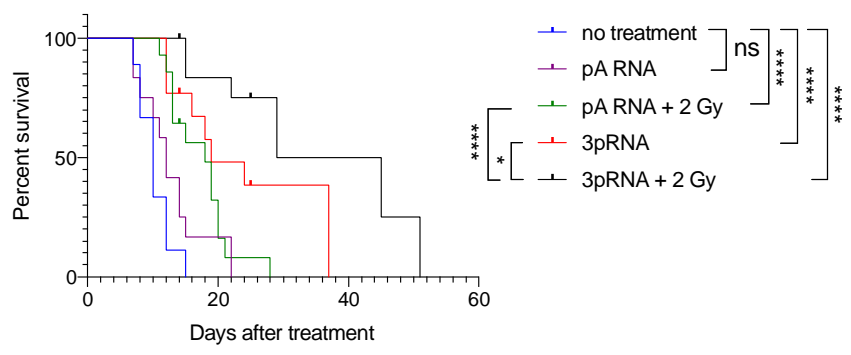

B

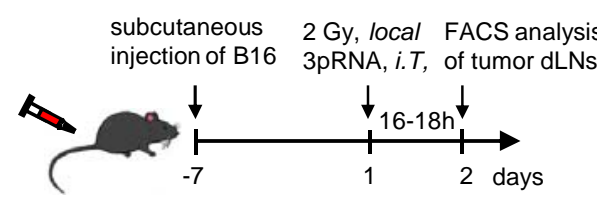

$6-8$ week old

C57BL/6 mice

Immune cell activation in tumor-draining lymph node after $16 \mathrm{~h}$

NK cells

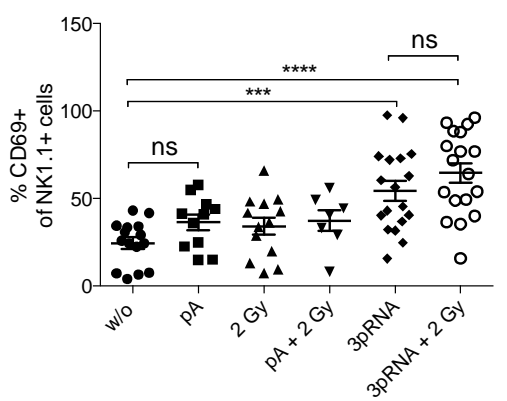

CD4+ T cells

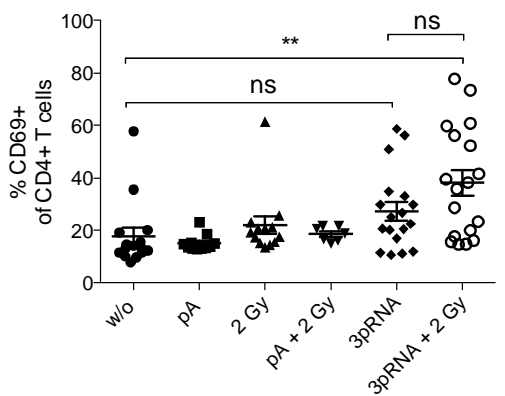

CD8+ T cells

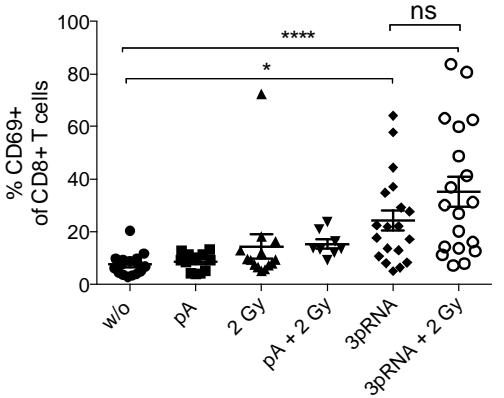

Figure 2: Concurrent irradiation and RIG-I immunotherapy prolongs the survival of melanoma-bearing mice.

(A) B16 melanoma cells, subcutaneously transplanted into C57/BL6 mice, were locally irradiated with 2 Gy, injected with 20 $\mu \mathrm{g} 3 \mathrm{pRNA}, 20 \mu \mathrm{g}$ control RNA (pA) or a combination of both, as indicated, and tumor size was measured regularly over 49 days. Mice with tumors larger than $10 \mathrm{~mm}$ diameter were euthanized for ethical reasons. Survival rate is shown as a Kaplan-Meier curve. Summary of 3 independent experiments with 3-5 mice per group and experiment. (B) Subcutaneously transplanted B16 cells were treated as indicated and approximately $16 \mathrm{~h}$ later immune cells from the tumor-draining lymph nodes were analyzed for the activation marker CD69. Mean \pm SEM of $n=3$ with 3-5 mice per group and experiment. ns, not significant; ${ }^{*} p<0,05 ;{ }^{* *} p<0,01 ;{ }^{* * *} p<0,001 ;{ }^{* * *} p<0.0001 ; 2-$ Way ANOVA. w/o: untreated, pA: control RNA, 3pRNA: 5'triphosphate RNA, non-irr: non-irradiated. 
bioRxiv preprint doi: https://doi.org/10.1101/2021.10.16.464638; this version posted October 16, 2021. The copyright holder for this preprint (which was not certified by peer review) is the author/funder, who has granted bioRxiv a license to display the preprint in perpetuity. It is made available under aCC-BY-NC-ND 4.0 International license.

A

$$
\mathrm{AC}_{20}+2 \mathrm{~Gy} \text { vs } \mathrm{AC}_{20}
$$

3pRNA vs $\mathrm{AC}_{20}$

$3 p R N A+2$ Gy vs $A_{20}$
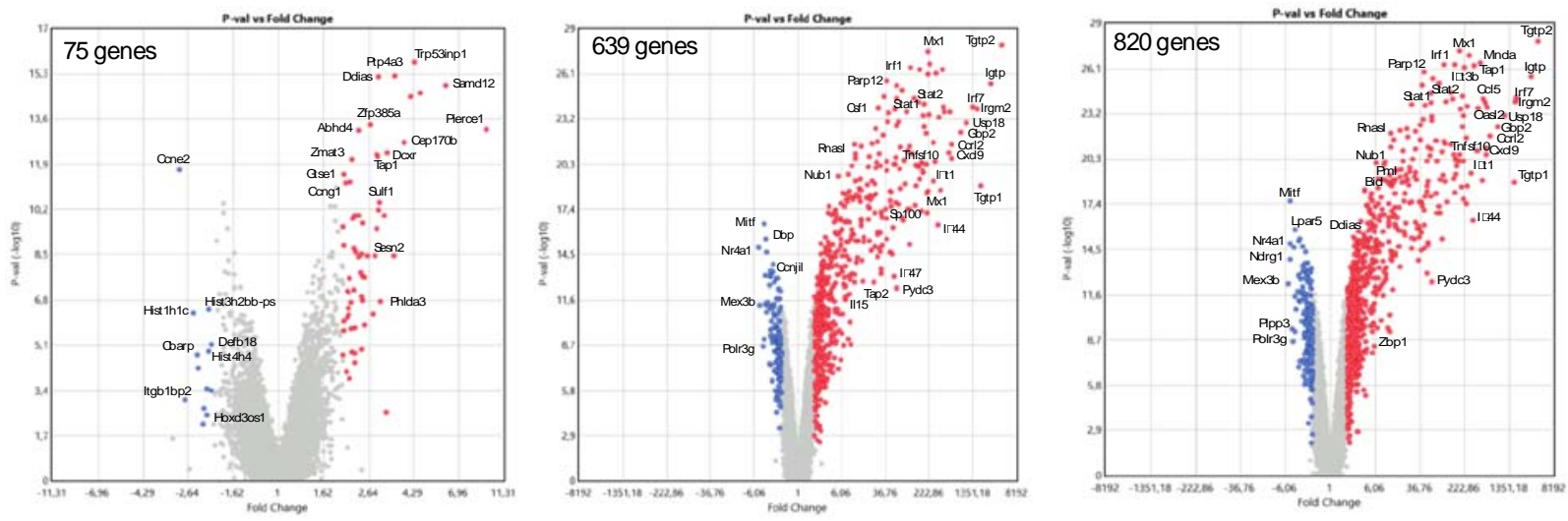

B

$\mathrm{AC}_{20}+2 \mathrm{~Gy}$ vs $\mathrm{AC}_{20}$

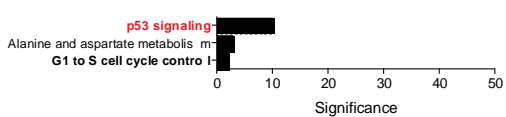

C

$3 p R N A+2$ Gy vs. 3pRNA

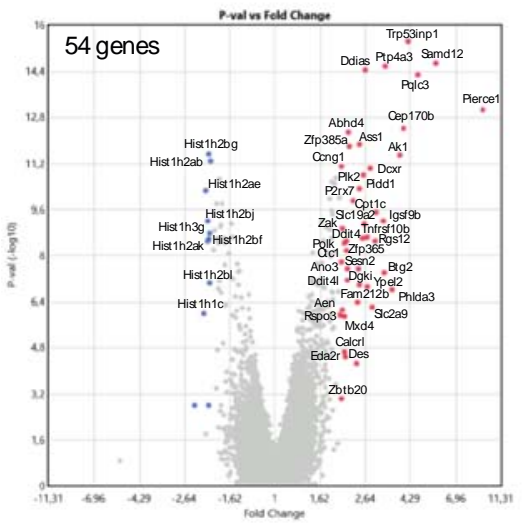

3pRNA vs $\mathrm{AC}_{20}$

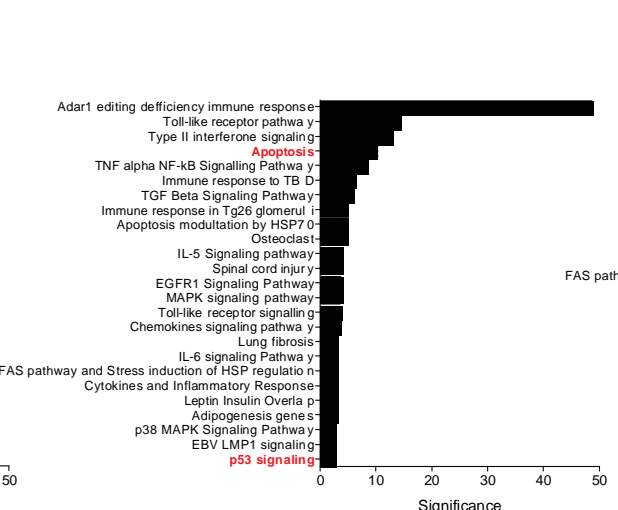

$3 p R N A+2$ Gy vs $A_{20}$

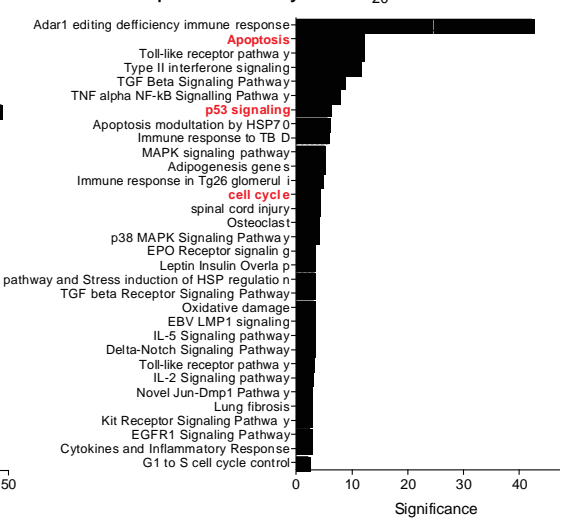

D

3pRNA + 2 Gy vs 3pRNA

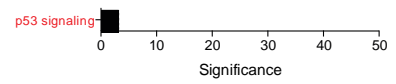

Figure 3: Whole-genome transcriptional analysis of B16 cells treated with the combined RIG-I radioimmunotherapy reveals activation of p53 signaling. Gene expression analysis (Affymetrix GeneChip) of B16 total RNA $6 \mathrm{~h}$ after stimulation with $50 \mathrm{ng} / \mathrm{ml} 3 \mathrm{pRNA}$ or $\mathrm{AC}_{20}$ control and 2 Gy irradiation alone or in combination. (A) Volcano plots of single treatments and combined treatment in comparison to the control-transfected B16 cells or (C) combined treatment vs. 3pRNA transfected cells. Colored data points show up- (red) or down- (blue) regulation of at least a 2 foldchange. FDR corrected p-value $<0,05$ (B, D) Pathway analysis (Wikipath) of genes found in (A) and (C) using the TAC software of Thermo Fisher ordered by significance. $\mathrm{AC}_{20}$ : control RNA, 3pRNA: 5'-triphosphate RNA. 
bioRxiv preprint doi: https://doi.org/10.1101/2021.10.16.464638; this version posted October 16, 2021. The copyright holder for this preprint (which was not certified by peer review) is the author/funder, who has granted bioRxiv a license to display the preprint in perpetuity. It is made available under aCC-BY-NC-ND 4.0 International license.

A

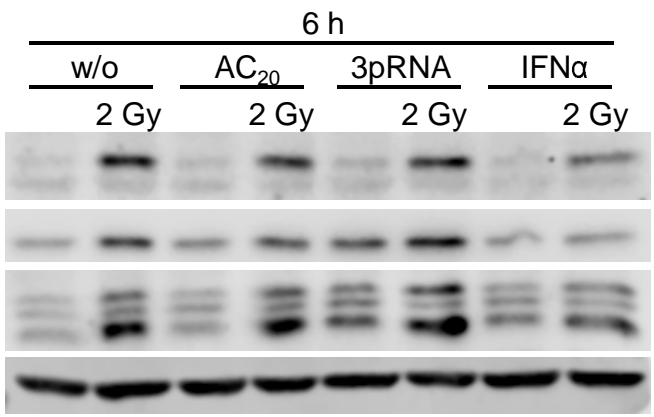

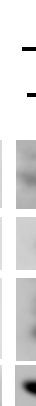

B

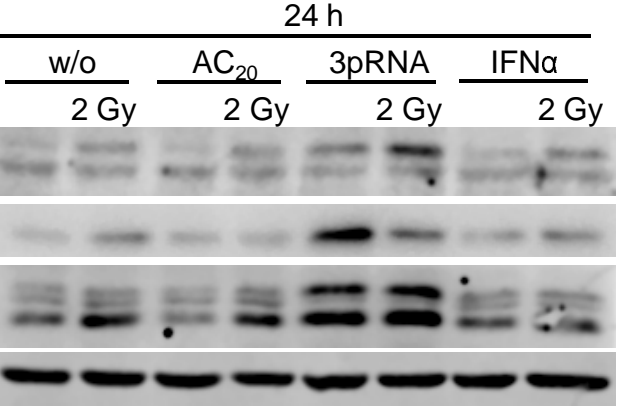

$\frac{24 \mathrm{~h}}{\frac{\mathrm{AC}_{20}}{2 \mathrm{~Gy}} \frac{3 p R N A}{2 \mathrm{~Gy}}}$

p-p53

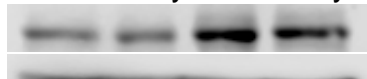

ATM

p53

Puma

Actin

$24 \mathrm{~h}$
Actin

$\mathrm{p} 21$

Actin
C

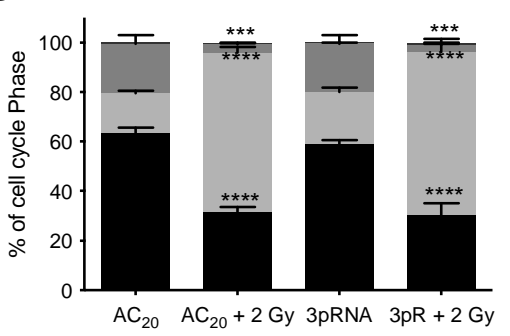

$12 \mathrm{~h}$

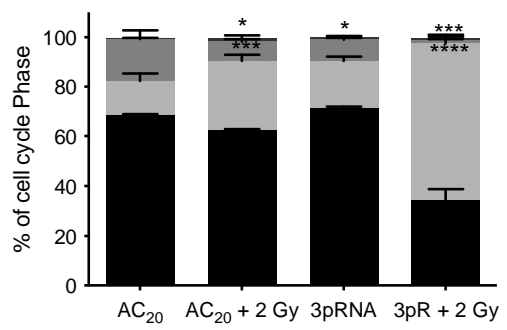

Figure 4: Combined RIG-I radio-immunotherapy induces p53 pathway activation and prolongs cell-cycle arrest. Western-blot analysis of (A) phospho- and total-p53 protein, as well as Puma expression and (B) ATM and p21 expression after irradiation with $2 \mathrm{~Gy}$, transfection of $50 \mathrm{ng} / \mathrm{ml} 3 \mathrm{pRNA}$, or the combination of both in B16 cells at the indicated time points. Actin served as a protein-loading control. (C) Flow-cytometric cell-cycle analysis of B16 cells stained with propidium iodide and treated with $50 \mathrm{ng} / \mathrm{ml} 3 \mathrm{pRNA}$ and/or 2 Gy after the indicated time points. Mean and SEM of $n=2$. ns, not significant; ${ }^{*} p<0,05 ;{ }^{* *} p<0,01 ;{ }^{* * *} p<0,001 ;{ }^{* * *} p<0.0001$; two-way ANOVA. AC 20 : control RNA, 3pRNA: 5'-triphosphate RNA. 
bioRxiv preprint doi: https://doi.org/10.1101/2021.10.16.464638; this version posted October 16, 2021. The copyright holder for this preprint Awhich was not certifid by peer review) is Be author/funder, cell death induction after $48 \mathrm{~h}$
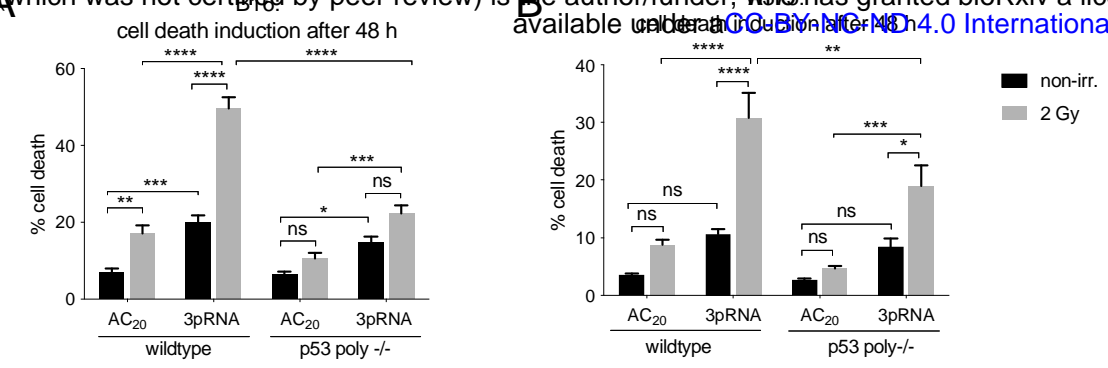

C

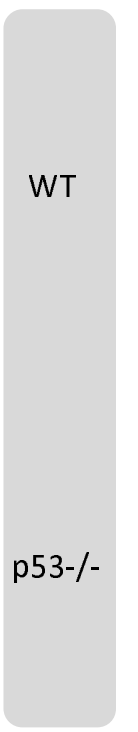

D

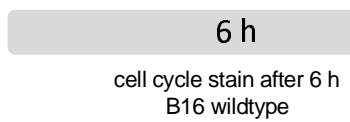

B16 wildtype

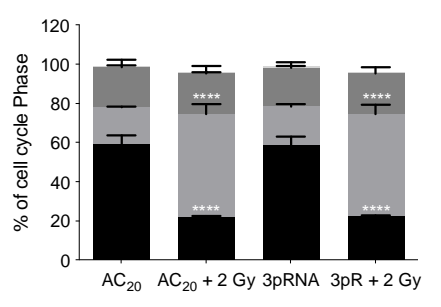

cell cycle stain after $6 \mathrm{~h}$

B16 p53 poly-/- KO

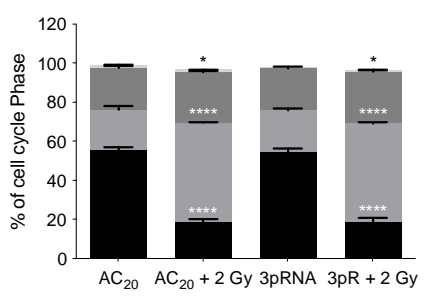

B16:

Calreticulin expression after $48 \mathrm{~h}$

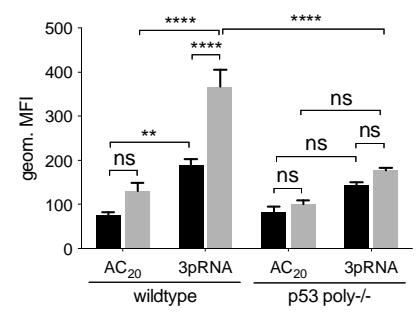

$24 \mathrm{~h}$

cell cycle stain after $24 \mathrm{~h}$

B16 wildtype

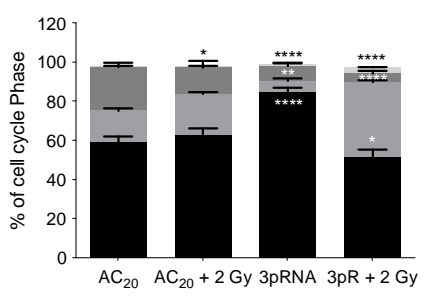

cell cycle stain after $24 \mathrm{~h}$

B16 p53 poly-/- KO

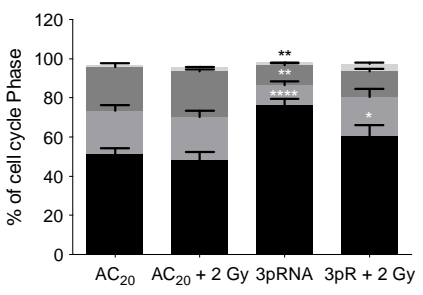

A375:

E
$48 \mathrm{~h}$

cell cycle stain after $48 \mathrm{~h}$

B16 wildtype

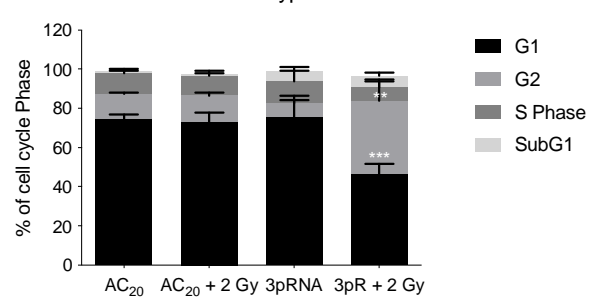

cell cycle stain after $48 \mathrm{~h}$ B16 p53 poly-/- KO

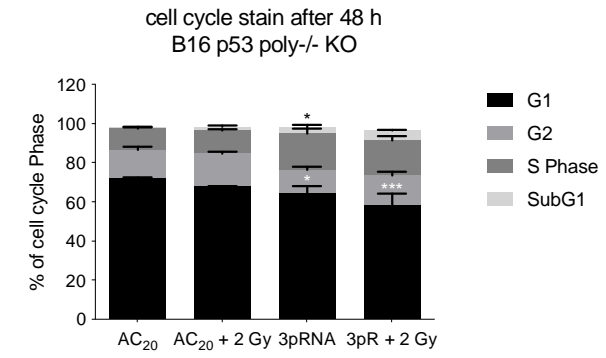

Calreticulin expression after $48 \mathrm{~h}$

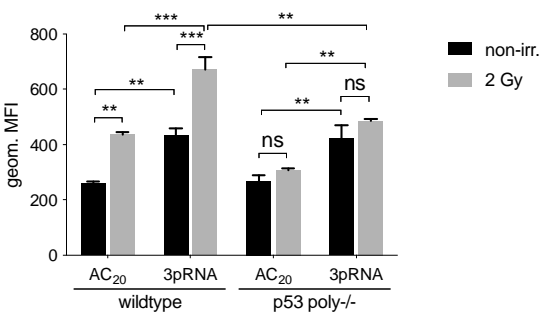

$\mathrm{F}$

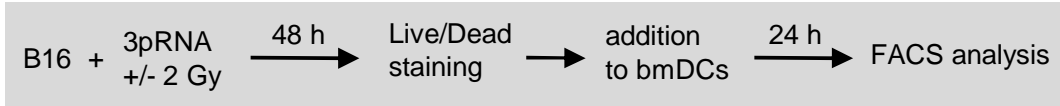

DC efferocytosis after $24 \mathrm{~h}$ coculture

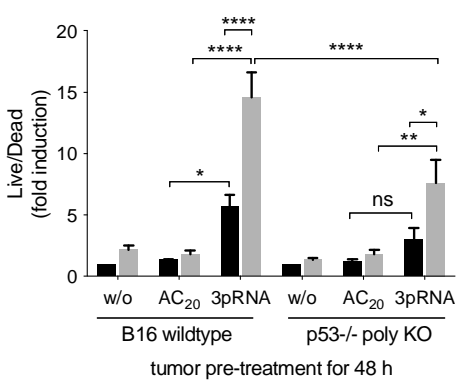

DC CD86 upregulation after $24 \mathrm{~h}$ coculture

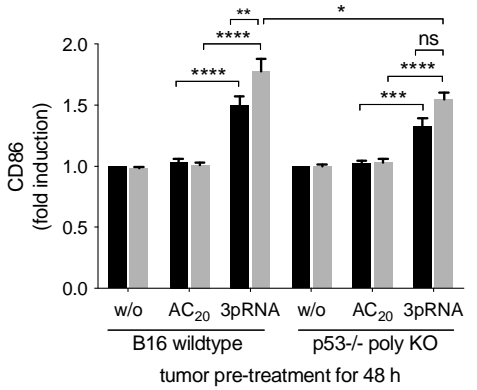

DC CD69 upregulation after $24 \mathrm{~h}$ coculture

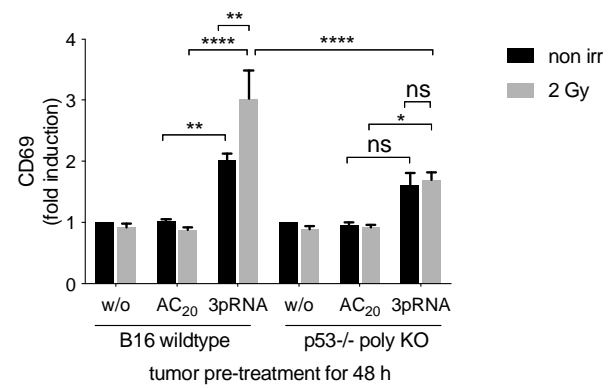

Figure 5: Knocking out p53 reduces the response of melanoma cells to combination treatment. (A-E) B16 or A375 wildtype and p53 polyclonal $K O$ cells were transfected with $50 \mathrm{ng} / \mathrm{ml} 3 p R N A, A C_{20}$ control RNA, or these in combination with 2 Gy irradiation. (A, B) Induction of cell death was quantitated via Annexin V/7AAD staining and analyzed by flow cytometry in B16 (A) and A375 (B) cells. (C) Flow-cytometric cell-cycle analysis with Hoechst 33342 at the indicated time points in B16 cells. (D, E) Surface calreticulin expression of B16 (D) and A375 (E) cells was monitored $48 \mathrm{~h}$ after treatment by flow cytometry. (F) B16 wildtype and p53 poly KO cells were transfected with $200 \mathrm{ng} / \mathrm{ml} 3 \mathrm{pRNA}$ and irradiated simultaneously with 0 or 2 Gy. $48 \mathrm{~h}$ later cells were stained by Live-Dead eFluor780 stain and cocultured with bone-marrow derived DCs overnight. Activated DCs were analyzed by flow cytometry the next day. p53 polyclonal knockout cells were generated by using the CRISPR/Cas9 system. All data are shown as the mean and SEM of $n=10$ (A), $n=5(D)$, or $n=3(B, C, E, F) .{ }^{*} p<0,05 ;{ }^{* *} p<0,01 ;{ }^{* * *} p<0,001 ;{ }^{* * * *} p<0.0001$; two-way ANOVA. ns: not significant, $A C_{20}$ : control RNA, 3pRNA: 5'-triphosphate RNA, non-irr: non-irradiated 
bioRxiv preprint doi: https://doi.org/10.1101/2021.10.16.464638; this version posted October 16, 2021. The copyright holder for this preprint (which was not certified by peer review) is the author/funder, who has granted bioRxiv a license to display the preprint in perpetuity. It is made available under aCC-BY-NC-ND 4.0 International license.

A

Immune-cell activation in tumor-draining lymph node after $16 \mathrm{~h}$

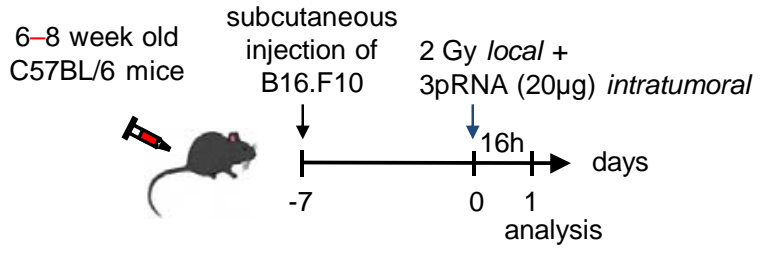

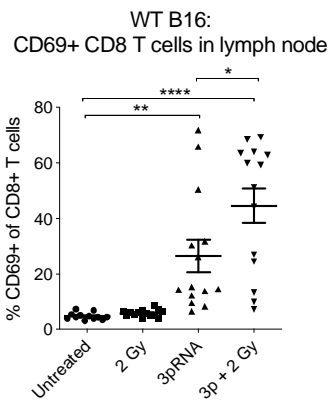

WT B16: CD69+ CD4 T cells in lymph node

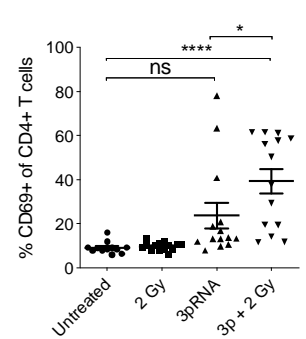

p53 $3^{-1-}$ B16:

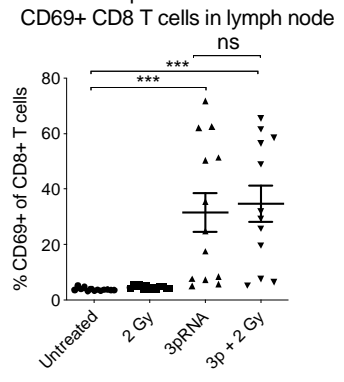

p53 1 - B16:

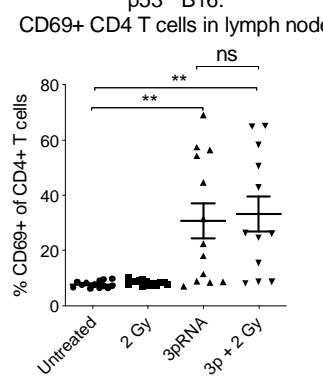

B
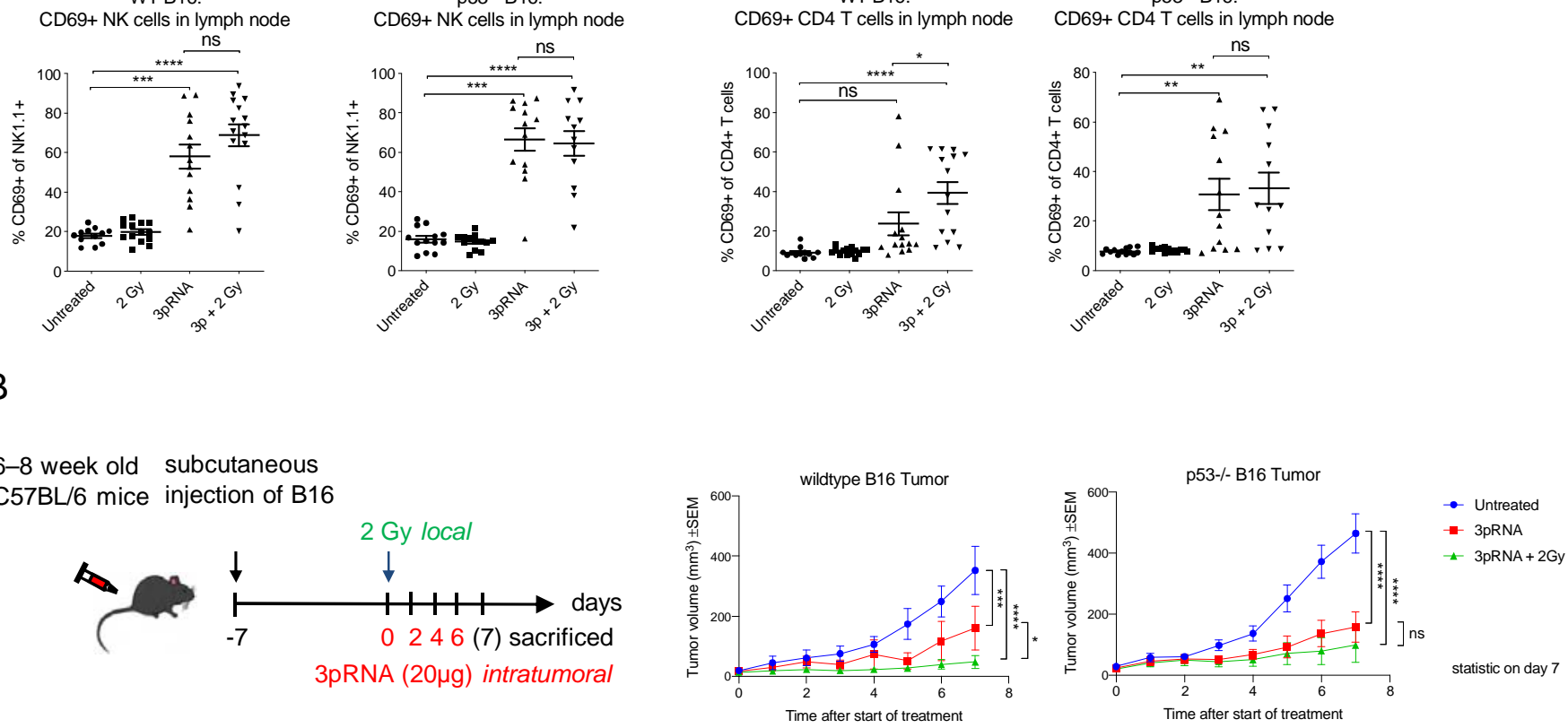

Figure 6: RIG-I immunotherapy is still effective in p53 KO melanoma, but the enhanced combinatorial efficiency with radiotherapy is abolished. (A) B16.F10 melanoma wildtype or p53 polyclonal knockout cells were subcutaneously transplanted into C57/BL6 mice and then locally irradiated with 2 Gy, injected with $20 \mu \mathrm{g} 3 \mathrm{pRNA}$, or a combination of both. $16 \mathrm{~h}$ later the mice were sacrificed. Tumor-draining lymph nodes were analyzed by flow cytometry for CD69 surface expression of activated $\mathrm{CD}^{+}, \mathrm{CD} 4^{+} \mathrm{T}$ cells, and NK1.1+ NK cells. Mean and SEM of $\mathrm{n}=3$ with 3-5 mice per group and experiment. (B) Mice were treated as indicated over 7 days and the tumor size was measured daily. Mean and SEM of $n$ $=3$ with 3-5 mice per group and experiment. ns, not significant; ${ }^{*} p<0,05 ;{ }^{* *} p<0,01 ;{ }^{* * *} p<0,001 ;{ }^{* * *} p<0.0001$; one-way ANOVA. 3pRNA: 5'-triphosphate RNA 
A

Annexin V
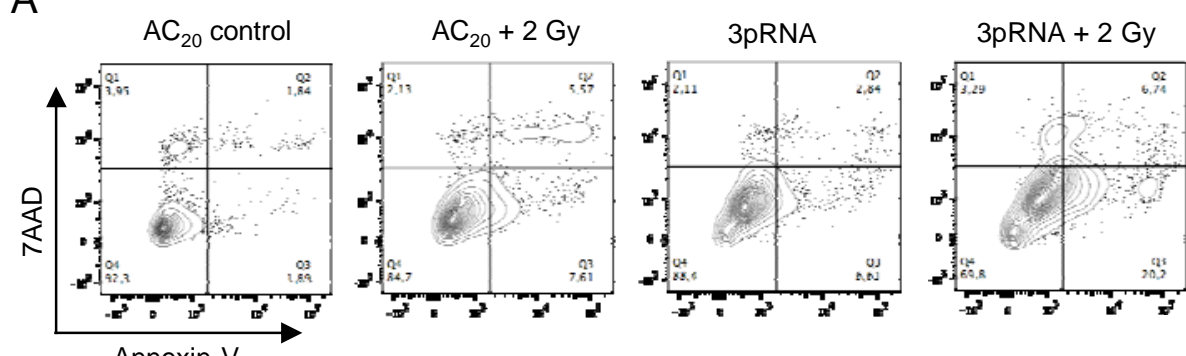

B

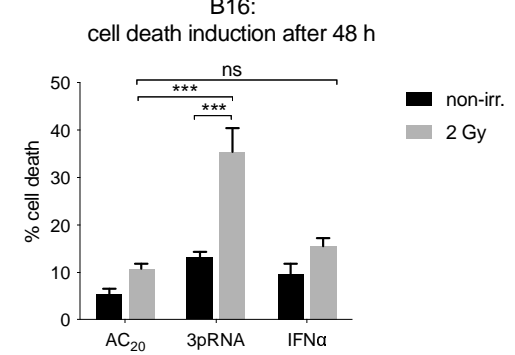

C
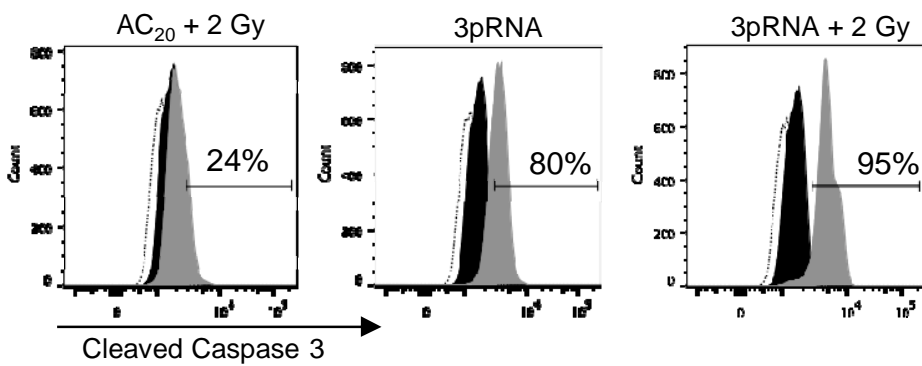

F

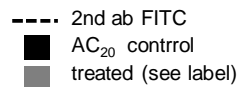

E
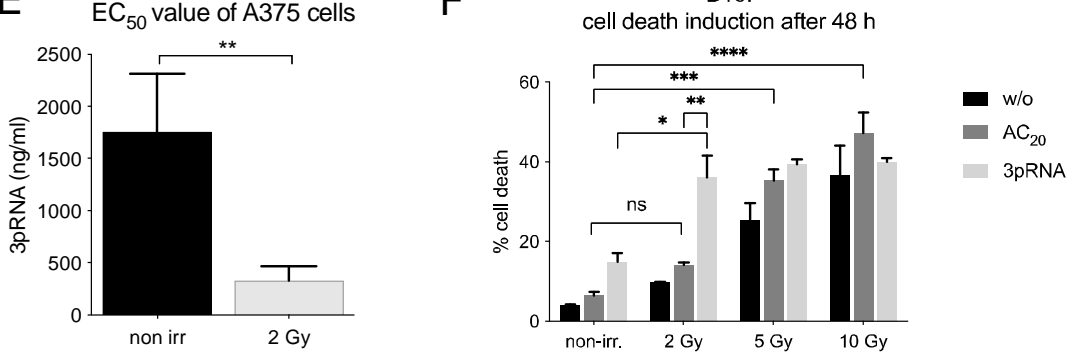

$\mathrm{H}$ B16:
$200 \mathrm{ng} / \mathrm{ml}$ 3pRNA after $48 \mathrm{~h}$

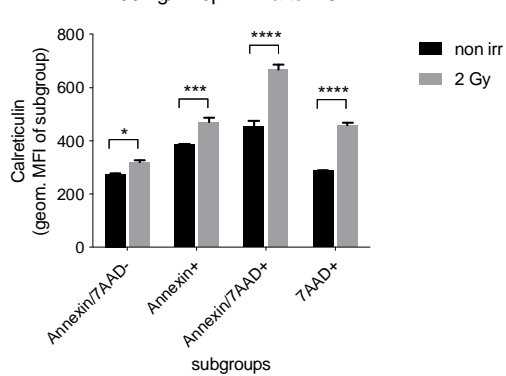

B16:

Activation of Casp3 after $24 \mathrm{~h}$

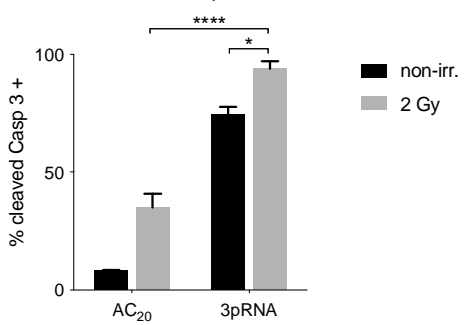

G B16:
$200 \mathrm{ng} / \mathrm{ml}$ 3pRNA after $48 \mathrm{~h}$
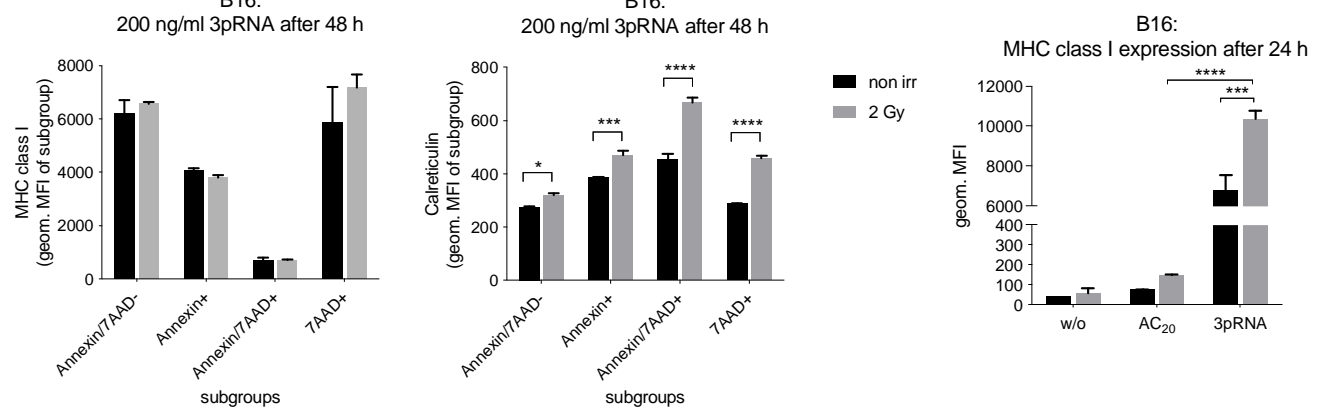

I

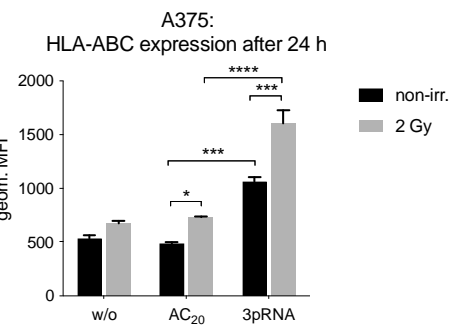

Supplementary Figure 1: Irradiation enhances 3pRNA-induced immunogenic cell death in melanoma cells, as well as uptake by and co-stimulation of dendritic cells. $B 16$ cells were transfected with $50 \mathrm{ng} / \mathrm{ml} 3 \mathrm{pRNA}$ or $\mathrm{AC}_{20}$ control RNA and simultaneous irradiated with 0 or 2 Gy. (A) Gating strategy of Annexin V/7AAD staining. (B) Cells were additionally stimulated with $1000 \mathrm{U} / \mathrm{ml}$ recombinant IFN $\alpha$ and after $48 \mathrm{~h}$, cell death was detected by Annexin V/7AAD staining. (C) Intracellular staining of activated, cleaved caspase 3 by fluorescently labeled antibody was measured after $24 \mathrm{~h}$ by flow cytometry. (D,E) Quantification of apoptosis induction by Annexin V/7AAD staining in B16 (D) and A375 (E) cells, $48 \mathrm{~h}$ after titration of 3pRNA concentration with and without $2 \mathrm{~Gy}$, as shown in Fig. 1C,D. EC Ev $_{50}$ value of 3pRNA concentration was calculated by using GraphPad Prism. (F) B16 cells were transfected with $50 \mathrm{ng} / \mathrm{ml} 3 \mathrm{pRNA}$ and given different irradiation doses. $48 \mathrm{~h}$ later, cells were stained with Annexin V/7AAD and analyzed by flow cytometry. (G) Annexin V/7AAD staining after $48 \mathrm{~h}$ of 3pRNA $(200 \mathrm{ng} / \mathrm{ml})$ transfection and 2 Gy irradiation of B16 cells was combined with $\mathrm{MHC}$ class I and calreticulin fluorescent labeling. $(\mathrm{H}, \mathrm{I}) \mathrm{MHC}$ I expression on the surface of B16 $(\mathrm{H})$ and $\mathrm{A} 375$ (I) cells $24 \mathrm{~h}$ after treatment, as detected by flow cytometry. (B-F) Mean and SEM, $\mathrm{n}=3$. (G-I) Representative with mean and SD of $n=3$. ${ }^{*} p<0,05 ;{ }^{* \star} p<0,01 ;{ }^{* \star *} p<0,001 ;{ }^{* * \star *} p<0.0001 ; 2$-way ANOVA. w/o: untreated, $A_{2}$ : control RNA, 3pRNA: 5 '-triphosphate RNA, non-irr: non-irradiated. 
bioRxiv preprint doi: https://doi.org/10.1101/2021.10.16.464638; this version posted October 16, 2021. The copyright holder for this preprint (which was not certified by peer review) is the author/funder, who has granted bioRxiv a license to display the preprint in perpetuity. It is made available under aCC-BY-NC-ND 4.0 International license.

A

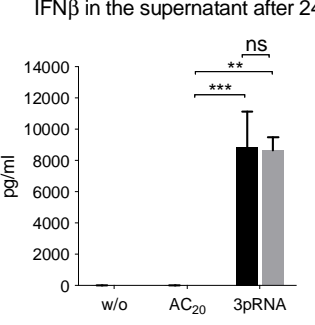

CXCL10 in supernatant after $24 \mathrm{~h}$

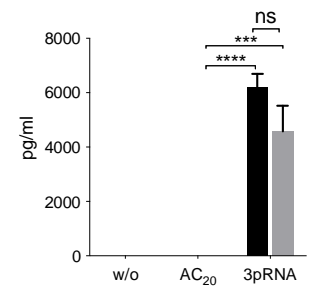

B
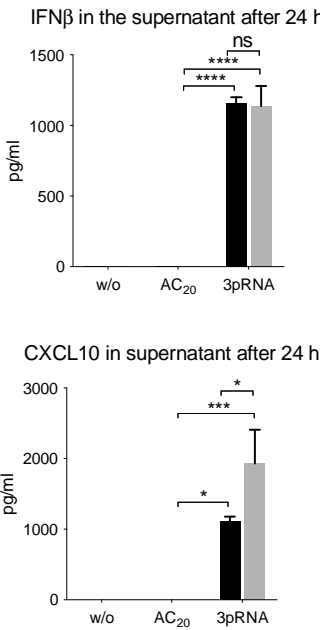

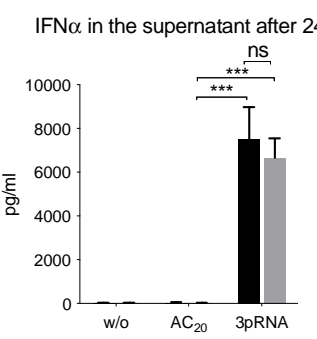

CXCL1 in the supernatant after $24 \mathrm{~h}$

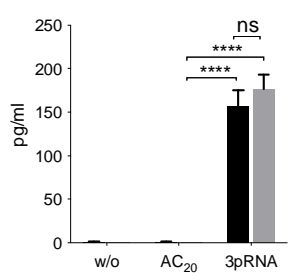

IL6 in the supernatant after $24 \mathrm{~h}$

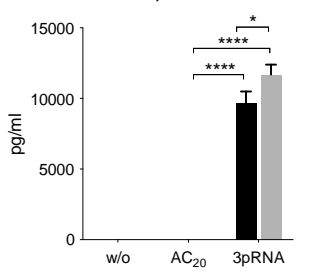

GM-CSF in the supernatant after $24 \mathrm{~h}$

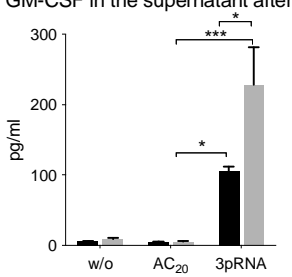

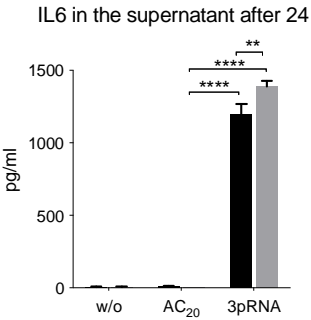

CCL5 / RANTES in the supernatant after $24 \mathrm{~h}$
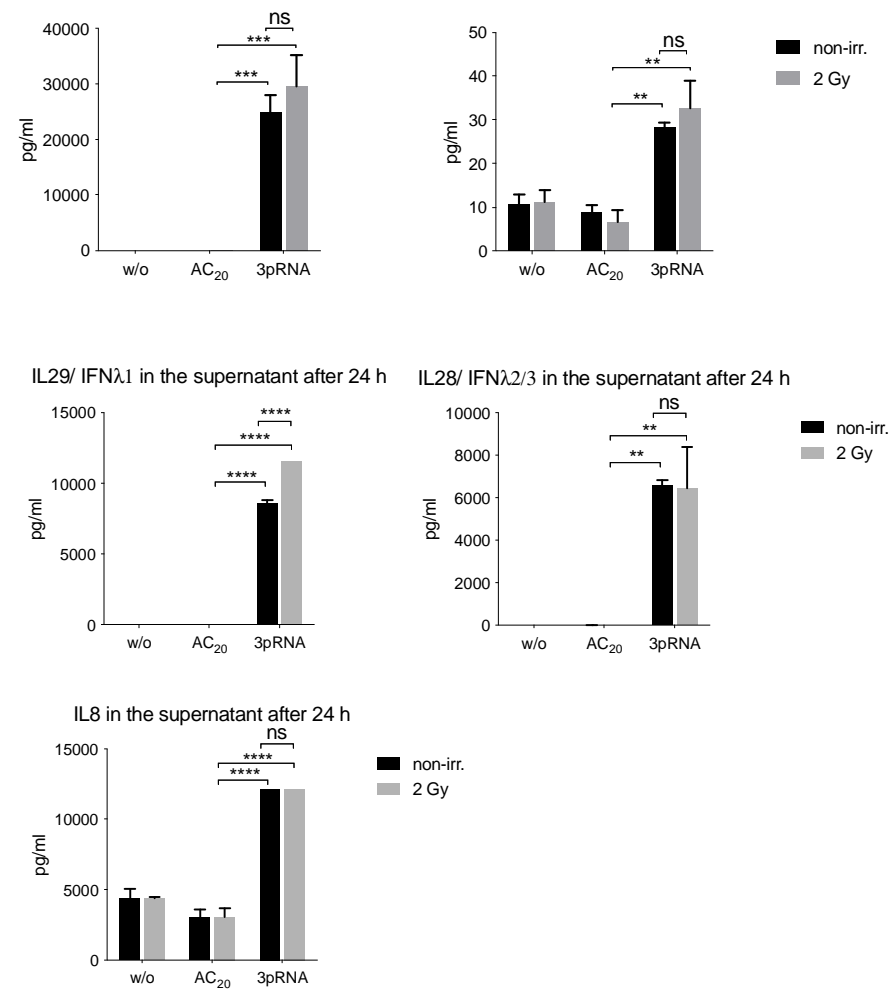

Supplementary Figure 2: 2 Gy irradiation has only minor influence on 3pRNA-induced cytokine release.

Melanoma cells were transfected with $50 \mathrm{ng} / \mathrm{ml} 3 p R N A$ or $\mathrm{AC}_{20}$ control RNA and simultaneously irradiated with 0 or 2 Gy. Supernatants were collected $24 \mathrm{~h}$ after treatment of B16 (A) and A375 (B) cells, and were analyzed by flow cytometric multiplex analysis to detect different cytokines and chemokines. Shown is the mean and SD of one experiment with biological replicates measured in technical replicates. Not detected: B16 (A): IL10, GM-CSF, IL1b, IFNg, IL12p70 A375 (B): TNFa, IFNa2, IL10, IL1b, IFNg, IL12p70 * $p<0,05 ;{ }^{* *} p<0,01 ;{ }^{* * *} p<0,001 ;{ }^{* * * *} p<0.0001 ; 2$-way ANOVA. w/o: untreated, $\mathrm{AC}_{20}$ : control RNA, 3pRNA: 5'-triphosphate RNA, non-irr: non-irradiated. 
bioRxiv preprint doi: https://doi.org/10.1101/2021.10.16.464638; this version posted October 16, 2021. The copyright holder for this preprint (which was not certified by peer review) is the author/funder, who has granted bioRxiv a license to display the preprint in perpetuity. It is made available under aCC-BY-NC-ND 4.0 International license.

A

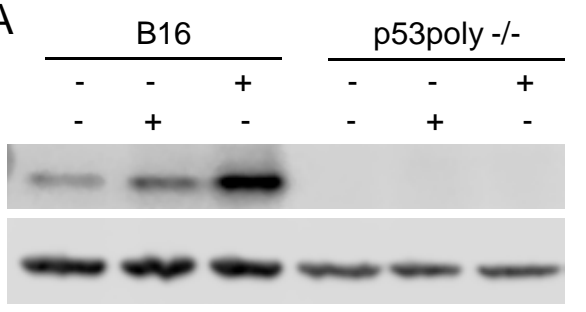

C

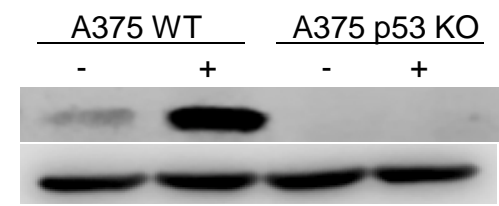

D

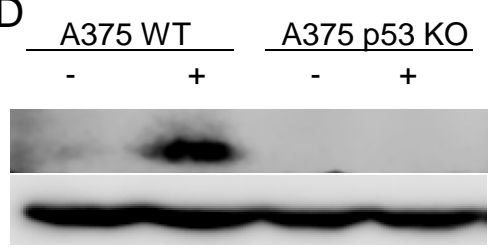

Actin
2 Gy

p53

Actin

2 Gy

p21

\section{$E$}

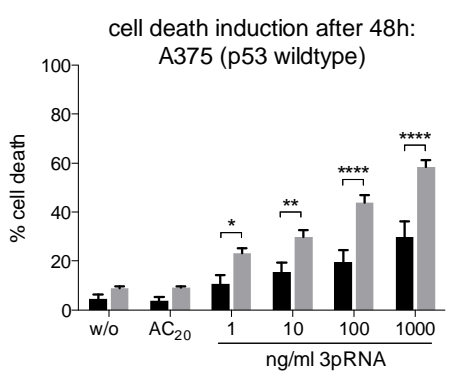

AMG232

2 Gy

p53

Actin
B

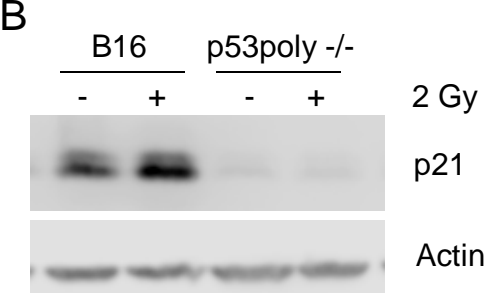

Actin

Supplementary Figure 3: Establishment of p53 polyclonal knockout melanoma and comparison of p53 wildtype and p53 mutated melanoma cells. Immunoblot analysis of p53 $2 \mathrm{~h}(\mathrm{~A}, \mathrm{C})$ and p21 $24 \mathrm{~h}(\mathrm{~B}, \mathrm{D})$ after irradiation with 2 Gy or treatment with $10 \mu \mathrm{M}$ AMG232 in B16 and A375 wildtype and p53 polyclonal $\mathrm{KO}$ cells as indicated. Actin served as a loading control. (E) Human melanoma cell lines A375 and SKmel28 were transfected with increasing concentrations of $3 p R N A$ and additionally irradiated with 2 Gy. Cell death was quantified $48 \mathrm{~h}$ later using Annexin V/7AAD staining and flow cytometry. Mean and SEM are shown from 3 independent experiments. p53 polyclonal knockout cells were generated by using the CRISPR/Cas9 system. * $p<0.05 ;{ }^{* *} p<0.01$; ${ }^{* * *} p<0.0001$; two-way ANOVA. AC 20 : control RNA, 3pRNA: 5 'triphosphate RNA, non-irr: non-irradiated 
bioRxiv preprint doi: https://doi.org/10.1101/2021.10.16.464638; this version posted October 16, 2021. The copyright holder for this preprint (which was not certified by peer review) is the author/funder, who has granted bioRxiv a license to display the preprint in perpetuity. It is made available under aCC-BY-NC-ND 4.0 International license.

$6 \mathrm{~h}$

\section{$\%$ Activation of Caspase 3 after $6 \mathrm{~h}$}

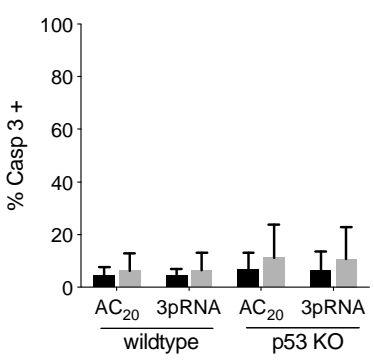

G1 \%Casp3 6h

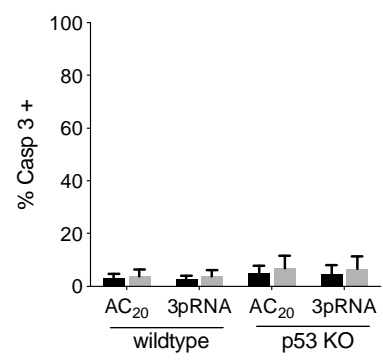

S Phase \%Casp3 6h

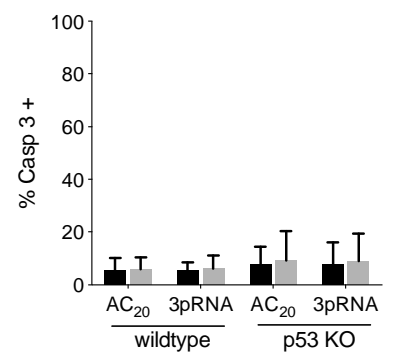

G2 \%Casp3 6h

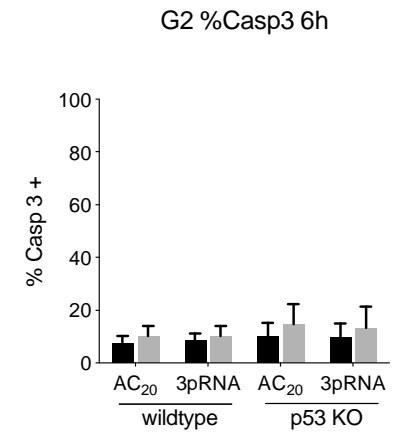

$24 \mathrm{~h}$

$\%$ Activation of Caspase 3 after $24 \mathrm{~h}$

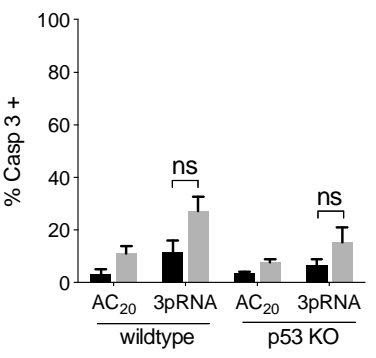

G1 \%Casp3 24h
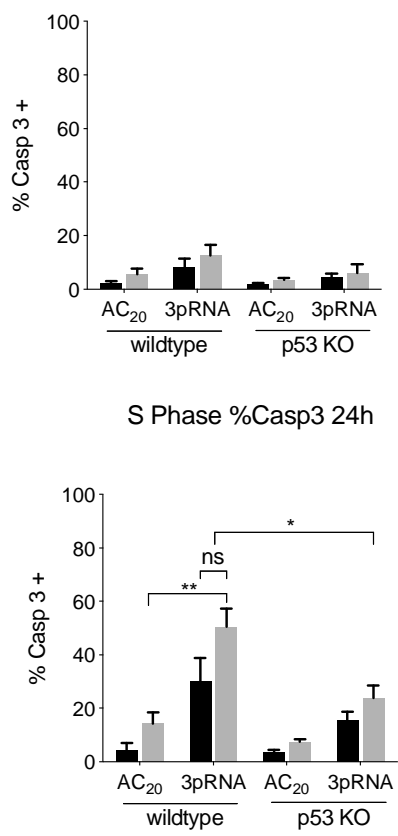

G2 \%Casp3 24h

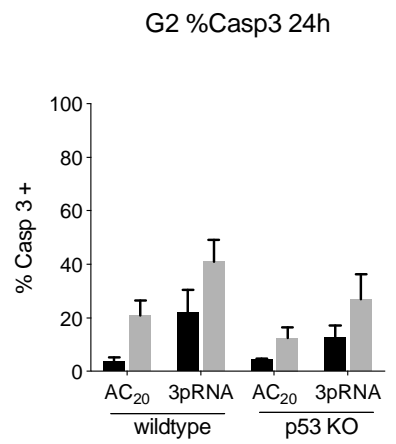

\section{$48 \mathrm{~h}$}

S Phase

G2

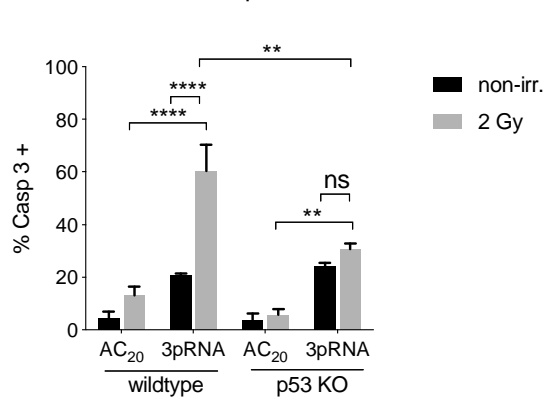

G1 \%Casp3 48h
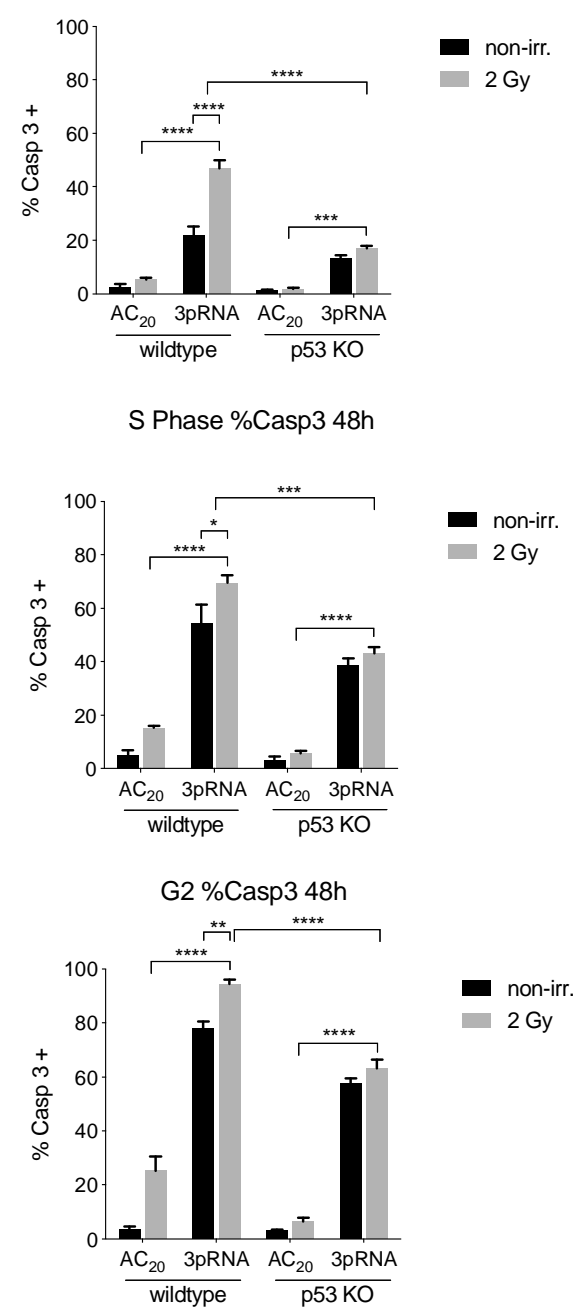

Supplementary Figure 4: Increased cell death correlates with prolonged G2/M cell cycle in combinatorial RIG-I radio-immunotherapy. Flow-cytometric cell-cycle analysis of B16 cells treated with $50 \mathrm{ng} / \mathrm{ml} 3 \mathrm{pRNA}$ and 2 Gy irradiation using genomic Hoechst 33342 stain in combination with intracellular staining with a caspase 3/7 cleavable dye at the indicated time points. p53 polyclonal knockout cells were generated by using the CRISPR/Cas9 system. * $p<0,05$; ${ }^{* *} \mathrm{p}<0,01 ;{ }^{* * *} \mathrm{p}<0,001 ;{ }^{* * *} \mathrm{p}<0.0001$; two-way ANOVA. ns: not significant, $\mathrm{AC}_{20}$ : control RNA, 3pRNA: 5'-triphosphate RNA, non-irr: non-irradiated 